\title{
TITLE:
}

\section{A HISTOLOGICAL STUDY ON THE AFFERENT INNERVATION OF THE LARGE BLOOD VESSELS}

\section{$\operatorname{AUTHOR}(\mathrm{S})$ :}

CHENG, YAT MAN

\section{CITATION:}

CHENG, YAT MAN. A HISTOLOGICAL STUDY ON THE AFFERENT INNERVATION OF THE LARGE BLOOD VESSELS. 日本外科宝函 1957, 26(1): 75-94

\section{ISSUE DATE:}

\section{7-01-01}

URL:

http://hdl.handle.net/2433/206336

RIGHT: 


\title{
A HISTOLOGICAL STUDY ON THE AFFERENT INNERVATION OF THE LARGE BLOOD VESSELS
}

\author{
by \\ Yat Man Cheng \\ From the 2nd Surgical Division, Kyoto University Medical School \\ (Director: Prof. Dr. Iasumasa Aoyagr) \\ Received for publication Nov. 17, 1956
}

\section{INTRODUCTION}

Histological studies concerning the innervation of blood vessels have been reported by many investigators. Michailow (1908) described an outer plexus in the adventitia (Adventitial Nervengeflecht), a deeper plexus at the border between adventitia and media (Grenznervengeflecht), and the deepest plexus in the media (Muskelnervengeflecht). GLASER (1914) and MitsuI (1929) also described 3 concentric zones of nervous networks; the deepest of which extended to the intima. On the other hand, both Hirsch (1925) and Stozhr Jr. (1928) observed a plexus on the surface of the circular muscle, but denied the existence of nerve fibres in the deeper layer of the musculature. Boeke (1932) had emphasized the abundance of nerve fibres forming a dense, intricate plexus throughout the entire layer of the media. Nonidez (1936) described nerve fibres in the superficial layers of the media, but denied the existence of a plexiform nervous structure throughout the media, as described by Boeke.

Next, studies concerning the afferent nerve terminations have been described by relatively few investigators. These terminations are known as presso-receptors, and are confined to certain areas; such as the carotid sinus, aortic arch, proximal portion of the aorta and the pulmonary artery. They were described by Telio (1924), Mitsur (1929), Sunder-Plassmann (1930), Muratori (1932), Takino (1933), Stoehr Jr. (1933), Nonidez (1935), Netrieship (1936) and Seto (1937). These receptive structures are described as diffuse arborizations, the branches of which were slender and end in fine terminal nets. Most of these structures were limited to the adventitia, and only a few of them were described in the media.

It is a well known fact that the staining of the vascular nerves is a difficult task. A long period of fixation often gives rise to various artefacts, which will mislead us to erroneous interpretation of the nervous structures.

Recently, in 1954, WEDDELL introduced the application of "spreading factors" in the demonstration of tissue neural elements. He stated that the use of "spreading factors" assists the process of rapid and even tissue fixation and thus eliminates artefacts, which are known to result from the slow penetration of fixatives. Similarly, it makes the various agents used to stain or impregnate nerve fibres after fixation penetrate more rapidly and homogeneously and the results obtained are thus far 
more uniform. Moreover, in the case of silver impregnation, it also renders reticular and collagen fibres nonargyrophil.

Accordingly, this new process is applied to the present study, in which the author searched for the afferent nerve terminations in the middle portion of the common carotid artery, abdominal aorta and vena cava, which are to date still unexplored.

\section{MATERIALS AND METHODS}

All the materials were obtained from adult dogs.

Under general anaesthesia with sodium isomytal, the necessary blood vessels were exposed, and into the walls of which 2 to $3 \mathrm{cc}$. of hyaluronidase solution were injected (1,000 T. R. units solved in $1.0 \mathrm{cc}$. physiological saline). After 20 minutes, the animal was sacrificed by bloodletting, and the injected portion of the necessary blood vesssels were taken out and fixed in 15\% neutral formol solution. On the 3rd day of fixation, the specimens were sliced with the freezing microtome into frozen sections of $35 \sim 40 \mu$ thickness. The specimens were sliced in cross sections and longitudinal sections. The frozen sections were further fixed for $2 \sim 3$ days, and were submitted to impregnation.

For impregnation, JABONERo's silver carbonate method was employed. The procedure is as follows:-

1, Wash the section with distilled water for one hour.

2, Immerse in $20 \%$ silver nitrate solution sheltered from light for 1 hour. In the summer season the time can be shortened, and prolong the time in the winter season.

3 , Wash in distilled water for 30 seconds.

4, Place in $20 \%$ neutral formol solution; this solution is prepared by diluting the mother neutral formol with running water, and placed in 5-6 plates. The sections are transferred to these plates one by one until the white precipitation disappears. This process must be completed within 10 minutes.

5 , Wash in distilled water for 1 minute, during which time the sections are vigorously stirred.

6, Prepare 2 plates of silver carbonate solution. To one of them add $3 \sim 4$ drops of ammonia, and a slice is placed for testing. If the slice gradually takes gold yellow color within $30 \sim 60$ seconds, the same amount of ammonia is added to the other plate, and the whole sections are placed in it. The sections gradually change from yellow to deep tobacco brown within $5 \sim 10$ minutes. If the section turns yellow too quick, add more drops of ammonia; if the contrary, reduce the amount of ammonia.

7, Wash in distilled water for 5 minutes.

8, Differentiate in acetic water (3 drops of acetic acid in I cc. of distilled water) for $2 \sim 3$ minutes. The sections turn from dark brown to gold yellow.

9, Wash in distilled water for 3 times.

10 , Place in $0.2 \%$ gold chloride solution for 10 minutes. 
11 , Fix in $5 \%$ sodium thiosulfate solution.

12, Wash, dehydrate and mount in balsam.

The silver carbonate solution is prepared in the following way: To $50 \mathrm{cc}$. of $20 \%$ silver nitrate solution an excess amount of saturated solution of sodium carbonate is added to produce milky yellow precipitate of silver carbonate. The precipitate is washed thoroughly with distilled water. Decant, and all the precipitate is dissolved with the least necessary amount of ammonia. Add $250 \mathrm{cc}$. of distilled water to the solution, and preserve in a brown flask. The solution is preferably to be stored in dark cool place, and it is available for several months. An important point on the preparation of this solution is that the addition of ammonia should be suspended just before all the silver carbonate precipitates dissolve completely.

\section{MICROSCOPICAL OBSERVATION}

In 1932 Stoenr Jr. and ReISER described the peripheral pattern of the autonomic nerve system as a fine network structure, which they have nominated "Terminalreticulum". Similarly, JABONERo (1953) described "système des fibres nerveuses protoplasmiques", which is a fine network structure enclosed in a band of protoplasm. These nervous structures form a closed network, and never terminate in free endings. In agreement with this theory, $\mathrm{H}$. Sexo insisted that the nerve fibres, which terminate freely in the periphery without forming the "Terminalreticulum", should be considered as sensory nerves, and that these sensory nerves could be easily differentiated from the autonomic nerves by their thickness.

In the adventitia, an abundance of JABONERo's syncytium nerveux is observable (Figs. 1 and 2), but though some hundreds of preparations have been inspected, none of them showed any trace of the network structure in the media and intima. A) Common carotid artery.

A thick myelinated nerve fibre running along in the adventitia abruptly changes its course and proceeds into the media in a perpendicular or an oblique direction (Figs. 3 and 4). There are some 7 to 12 concentric undulatory layers of elastic fibres according to the thickness of the vascular wall. These elastic fibres remain unstained and lucid. The nerve fibre after entering the media gives off branches along the elastic fibres at the outer layer of the media (Fig. 5). It proceeds further towards the inner layer and again gives off branches along the elastic fibres (Fig. 6), and finally it terminates freely in the connective tissue between the smooth muscle cells. No direct contact between the termination and the muscle cell is observable (Figs. 7 and 8). By way of the above described ramification, nerve fibres running in various depths can be observed (Fig. 9). Each nerve fibre running along the elastic fibres gradually decreases its thickness, and terminates as a tapering ending (Figs. 10 and 11). Occasionally, some varicosities and bead-like swellings are observed in the midway, and a loop formed near the termination (Figs. 12, 13 and 14). Rarely, a complicated arborization is observed (Fig. 15). As a rule a branch runs along a certain layer of the elastic fibres and terminates in the vicinity, but sometimes it deviates from its course and proceeds towards another 
layer (Figs. 16 and 17).

The above described nerves are observed in cross sections. In longitudinal sections a thick nerve fibre is seen running vertically along the major axis in the media (Fig. 18).

These intrinsic vascular nerves distribute over the outer $1 / 2$ to $2 / 3$ layer of the media. In the far inner layer and in the intima there are no traces of any neural element observable.

B) Abdominal aorta.

In the media of the abdominal aorta the same pattern of nerve distribution is observed as in the case of the common carotid artery. Namely, one or more nerve fibres enter into the media from the adventia giving off branches, and proceed towards the inner layer (Figs. 19, 20 and 21). Each branch runs along the elastic fibres for a rather long distance, and terminates freely in the connective tissue without forming any specific end structures (Figs. 22, 23 and 24). Sometimes, the branch further ramifies in due course (Fig. 25). In rare occasions, the fibres form a loop (Fig. 26), or terminate in complicated arborizations (Fig. 27).

Next, in longitudinal sections nerves are seen running in a longitudinal direction with reticulated swellings and varicosities, which are characteristics of the sensory nerves (Figs. 31 and 32). There are also branches running in horizontal directions (Figs. 28 and 33 ).

In the case of the abdominal aorta, the nerve distribution is also limited to the outer $1 / 2$ to $2 / 3$ layer of the media, and no trace of any neural element is observed further than this limit. Also the network structure of SToEHR's "Terminalreticulum" is not observed in the entire musculature.

From the above stated observations a pattern of the intrinsic nerve innervation of the arterial wall can be assumed as shown in the schema (Fig. 34).

C) Vena cava inferior.

The nerve distribution in large veins is far more scarce than the large arteries, but the author has been able to pursue a similar thick wavy nerve fibre to the endothelial layer of the intima.

Bundles of thick nerve fibres can be seen circling the vein in the thick layer of the adventitia (Fig. 29). Then, one of the nerve fibres penetrates into the media (Fig. 30), and continues its course along the media (Figs. 35 and 36). When it nears its termination, the fibre abruptly turns its course towards the intima and terminates freely, without forming any specific terminal structure, under the endothelial layer of the intima (Figs. 37, 38 and 39). Only in one case has the author observed a forked termination in the intima (Fig. 40).

There are few or no elastic fibres existing in the thin muscular layer, and the nerve fibre does not ramify as seen in the arteries.

Supplement: Afferent vascular nerve of human popliteal vein.

The material of this specimen was obtained from an adult female patient suffering from sarcoma of the femur. Fyaluronidace solution was injecter into the wall of the popliteal vein in the same manner as previously described. This was perfo- 
rmed immediately after the leg was amputated.

As it is generally known that the larger veins of the extremities have a thicker layer of musculature than those in the abdominal cavity, the author has observed a more abundant nerve supply than in the vena cava. Unfortunately, in exposing the vein the author must have stripped off the adventitial tissues. Consequently, the state of nerve distribution in the adventitia was not revealed.

In the media quite near the middle layer of the musculature, thick undulated nerve fibres can be seen running in a circular direction for quite a long distance. These nerve fibres proceed alongside the muscle bundle or in the connective tissues in between the muscle bundles, and terminate freely without forming any specific structure at the end. Varicosities and reticular swellings can also be observed along its course.

In this specimen nerve fibres are seen only in the media, and the author has been unable to detect any nerve terminations in the intima, as in the case of the vena cava. (Figs. 41, 42, 43, 44 and 45).

\section{EXPERIMENTAL OBSERVATIONS ON THE AFFERENT VASCULAR INNERVATION}

OTsu of our laboratory has, in his study on the visceral afferent innervation, revealed the fact that visceral sensory nerve fibres have their nerve cells in the spinal ganglia of the dorsal roots of the spinal cord; the postganglionic fibres have no interposing nerve cells till their terminations. Likewise, the afferents in the vagus nerve also have no interposing cells distal to the jugular and nodular ganglions. According to this fact, Orsu and many other investigators of our laboratory have been able to determine the source of the sensory nerves in various visceral organs by performing vagotomy in which, according to WALLER's law, these sensory nerves showed secondary degeneration.

The afferent vascular innervation was assumed to be similar to those of the visceral organs; in fact, the nerve fibres observed in the media and the intima of the vascular wall, have a close resemblance to those of the visceral sensory nerves.

Hence, vagotomy and posterior rhizotomy were performed to prove experimentally that the vascular nerves, which have been described, are sensory in nature, and also to determine their source of distribution.

Adult dogs were used in the experiment.

\section{A) Vagotomy.}

About $2 \mathrm{~cm}$. of the right vagus trunk was resected distal to the ganglion nodosum. Specimens were taken $61 / 2$ days after operation, and were prepared as described previously.

Degenerated nerve fibres were observed in the media of the abdominal aorta. The axis-cylinder had broken down, and gave an appearance of a string of granules or beads along the wavy layer of the elastic fibres, or scattered granules in the connective tissues (Figs. 46 and 47). On the other hand, there were nerve fibres which remained intact in the media. These nerve fibres are probably of the nerves 
from the posterior roots of the spinal cord. In the case of bilateral vagotomy performed in the thorax distal to the anastomis of both of the vagus nerves, similar degeneration was observed in the media (Fig. 48).

In the media of the right common carotid artery, though granular degenerations were not observed, deeply impregnated nerve fibres with strong swelling, and also nerve fibres with vacuoles and partial severance were observed (Figs. 49, 50 and 51). These appearances may be considered as the early phase of degeneration.

B) Posterior rhizotomy.

The spinal cord was exposed by laminectomy, and the dorsal roots were carefully seperated through the ganglia. The dorsal roots were resected bilaterally at the point distal to the ganglia. Th. 9,10 and 11 were resected in this experiment, according to the physiological result of $\mathrm{K}$. TunEkAWA of our laboratory.

Specimens were taken from the abdominal aorta 3 days after the operation. Granular degenerations of the axis-cylinders were observed along the elastic fibres (Figs. 52 and 53). Nerve fibres with strong rugged swellings were also observed (Fig. 54). In the case of the specimen taken 5 days after rhizotomy, degenerated axis-cylinder particles had begun to vanish, and only dim remainders of the granules were observed in the media (Fig. 55). Hence, it may be concluded that the degeneration of the axis-cylinder reaches its maximal stage on the $3 \mathrm{rd}$ or 4 th day after posterior rhizotomy.

When inspecting the impregnated specimens one may often confuse the silver particles or specks attached to the surface of the specimen with the granular degeneration of the axis-cylinder. Therefore, by impregnation every effort must be exerted to avoid the precipitation of silver particles on the specimens. Obviously, the silver particles or specks are seen on the surface of the specimen, while the degenerated neural elements can also be seen under the surface by moving the focus of the microscope. Moreover, they may be differentiated by the tone of their color. Silver specks give a black color, while the degenerated neural elements give a deep bluepurple color.

From the results of the above experiments, a conclusion is obtained that these intrinsic vascular nerves are afferent fibres, and they are derived from both vagus and dorsal roots of the spinal cord.

\section{DISCUSSION}

By applying "spreading factors" to the vascular wall prior to impregnation, the author has been able to observe thick nerve fibres with free terminations in the media of the common carotid artery, abdominal aorta and in the intima of the vena cava of adult dogs; also in the media of human popliteal vein.

In achievement of the present study, the author is much indebted to Prof. Dr. G. WedDell.

There is an abundance of nerve plexus in the adventitia, and also ganglionic cells have been found by Glaser, Müller, Takino, Sunder-Plassmann, Stoehr Jr. and SETo etc. In the periphery beyond the nerve plexus or the ganglia of the 
adventitia, the autonomic nerves (efferent fibres) will form a reticulated sturucture as Stoenr's Terminalreticulum or Jabonero's syncytium nerveux. From this view point the thick nerve fibres, which terminate freely in the connective tissue of the media, should not be considered as autonomic or efferent nerves.

JABONERO maintained that syncytium nerveux is distributed numerously over the adventitia, but never cross the border of the media. Therefore, no neurofibrilles exist which have direct contact with the smooth muscle cells of the media, and the impulse must be considered to reach the muscle cells via chemical transmission. In fact, in all the specimens not one of them showed any trace of the network structure of the peripheral autonomic nerve in the media or the intima.

But in some occasions a fine slender nerve fibre is seen running beside the thick nerve fibre. These thin fibres are lightly impregnated compared with the thick fibres, and neither reticulated swellings nor varicosities are observed along its course. Their morphological appearance is quite distinguishable from the thick undulated fibres. Should these fine slender fibres be considered as autonomic efferent fibres is a problem still to be studied.

M. ClaRA indicated that the morphologic characteristics of the sensory nerve endings are the specific structures which tend to expand its terminal surface. But G. WEDDELL emphasized that the terminal structures of sensory endings are usually free-ending arborizations, and the complicated terminations may be considered as artefacts. The observations obtained in this study quite agree with his opinion.

H. Seto described sensory nerve terminations of simple arborization in the aortic arch and pulmonary artery of human foetus. M. TAKINo described sensory nerve fibres in the media of the pulmonary artery which terminated freely in the connective tissues between smooth muscle bundles. He also stated that these nerve terminations have no direct relation to the muscle cells, and they should be considered as sensory in nature. According to these opinions, the vascular nerves, which the author has observed may also be considered as sensory in nature.

Generally, sensory nerves are considered to have myelin sheaths till the periphery. Myelin sheaths in the adventitia were easily stained, but they were not observed in the media, therefore, it may be considered that the nerve fibre probably loses its myelin sheath in entering the media.

W. Odermatr was one of the first who conducted an experimental study on vascular sensitivity. He had provoked vascular pain by expanding the artery mechanically. He explained that the pain was due to traction of the sensory nerve terminals in the adventitia. But, on the other hand, barium chloride is known to have a strong vasoconstrictive action, and the strong vascular spasm caused by it also provokes vascular pain. It is reasonable to think that the pain is provoked by the compression of the sensory terminals in the media rather than the traction of the adventitial sensory endings.

The author has not been able to observe any ganglionic cells or Pacinian corpuscles in the adventitia as described by Krause, Woolard, Rachmanow, Hirsch, Stoenr and SETo etc. These corpuscles are situated at the outer layer of the adventitia or in 
the connective tissues surrounding the blood vessel, and in exposing the vessels for the injection of hyaluronidase, the surrounding tissues with the corpuscles in it must have been stripped off.

K. TunekAw a our laboratory has recently succeeded in provoking vascular pain by inserting cardiac catheter with bipolar electrodes at an end into the blood vessels to stimulate electrically from inside. His physiological experiment has revealed that the afferent inpulse is conveych through the vagus and the dorsal roots of the spinal cord. This result coincides with the histological result of the present experiment.

Up to date, sensory terminations of the vcin still remain unclarified. H. Seto has reported of observing simple sensory terminations in the media of the vena cava of human foetus. He also stated that these terminations exist only during the foetal stage, and they may disappear after birth. The author has succeeded in discovering thick wavy sensory nerve fibres not only in the media of adult dog's rena cava, but also in the media of adult human popliteal vein.

Blood pressure is known to be regulated through the presso-receptive nerves in carotid sinus, aortic arch and other specific areas, and the author imagines the vascular nerve terminations found besides these portions will also contribute to the regulation of blood circulation.

\section{SUMMARY AND CONCLUSION}

Applying the injection of hyaluronidase to the material, and with the silver carbonate impregnation, thick undulated nerve fibres are observed in the media of adult dog's common carotid artery, abdominal aorta and human popliteal vein, and also in the intima of adult dog's vena cava; veins are much less innervated than arteries.

These nerve fibres with some exceptions generally terminate in simple tapering endings in the connective tissues between muscle bundles, and neither complicated terminal structures nor specific end apparati are observed. The distribution of these fibres is of a three dimensional pattern i.e. circular, radial and longitudinal. Although reticulated structure of the "Torminalreticulum" or the "syncytium nerveux" is not observed in the media and intima, fine slender fibres are observed in the media in some occasions. They may be consiclered as the autonomic efferent fibres, but a definite conclusion is not yet reached. The thick nerve fibres showed secondary degeneration when vagotomy and posterior rhizotomy were performed.

Finally, a conclusion is reached, that these thick nerve fibres are the intrinsic afferent nerves of the vascular wall, and are derived from both vagus and dorsal roots of the spinal cord.

An abstract of this study has been reported by Assist. Prof. Dr. Ch. Kimera of our clinic at the symposium of the International Society of Neurovegetative Research in Strassburg on 1st Oct. 1955.

I wish to cxpress my deepest gratitule toward Assist. Prof. Dr. Ch. Kimurd for his helpful advice and kind guidance throughout this study. 


\section{REFERENCES}

1) Bayliss, M. W.: The Vasomotor System. Longmans, N.Y. 1923. 2) Boeke, J.: Some Observations on the Structure and Innervation of Smooth Muscle Fibres. Jour. Comp. Neurol. 56, 27, 1932. 3) Clara, M.: Die Anatomie der Sensibilität unter besonderer Berücksichitgung der vegetativen Leitungsbahnen. Acta NeuroVeg, VII, 1-4. 1-31, 1953. 4) Glaser, W.: a) Die Nerven in der Blutgefässe des Menschen. Arch. f. Anat. u. Physiol. anat. Abt1. 189, 1914. b) Uber die Nervenverzwcigung innerhalb der Gefässwand. Dtsch. Zeitschr. f. Nervenheilk. Bd 50 ; 305, 1914. 5) Hirsch, L.: a) Über die Nervenversorgung der Gefässe im Hinblick auf die Probleme der periarteriellen Sympathektomie. Arch. f. Klin. Chirurg. Bd 137;281, 1925. b) Über den feineren Bau der Nerven der grössen Extremitätengefässe. Ebcnda. Bd 139 ; 225, 1926. 6) Jabonero, V.: Der anatomisches Aufbau des peripheren neurovegetativen System. Acta Neuro-Veg. Suppl. İ'; 1953. 7) Kerper, A.H.: a) The Innervation of Arteries of the Extremities. Anat. Rec. Bd 32, 235, 1926. b) The Distribution of Unmyelinated Nerve Fibres to the Arteries of the Extremities. Anat. Rec. Bd 35; 17, 1927. 8) Kimura, Ch.: a) Development of Dial Afferent Innervation Theory of the Viscera. Nihon Rinsho. 11; 2, 85, 1953. b) Visceral Sensory Nerves and Autonomic Nerves. Saishin Igaku, 9; 5, 34, 1954. 9) Krause, W.: Handbuch der menschlichen Anatomie. 1876. 10) Kure, T. and Okinaka, S.: Autonomic Nervous System. 1949. (in Japanese) 11) Kuntz, A.: Autonomic Nervous System. 157, 1947. 12) Langley, J. N.: The Autonomic Nerrous System. Cambridge, 1921. 13) Michailow, S.: Zur Frage über die Innervation der Blutgefässe. Ebenda, Bd 72, 540, 1908. 14) Mitsui, S.: Studies on the Nerves of the Blood Vessels. The Jour. of Orient. Med. X; 4., 49, 1929. 15) Müller, L.R.: Lebensnerven und Lcbenstriebe. Springer Verlag, 1931. 16) Müller, L. R. u. Glaser, W:: Über die Innervation der Gefässe. Dtsch. Zeitschr. f. Nervenheilk. Bd 46; 325, 1913. 17) Muratori.: Arch. Ital. Anat. Embr. 34, 1934. 18) Nettleship, W.A.: Experimental Studies on the Afferent Innervation of the Cat's Heart. Jour. Comp. Neurol. 64; 115, 1936. 19) Nonidez, J.F.: a) The Aortic (depressor) Nerve and its Associated Epithclioid Body, the Glomus Aorticum. Am. J. Anat. 57; 259, 1935. b) The nervous "terminal reticulum". I. Observations on the Innervation of Blood Vessels. Anat. Anz. 82; 348, 1936. c) Identification of receptor areas in venae cavas, and pulmonary veins which initiate cardiac acceleration (Bainbridge's reflex.) Am. J. Anat. 61; 203, 1937.20 ) Odermatt, W.: Die Schmerzempfindlichkeit der Blutgefässe und die Gefässreflex. Habilitationsschr. Basel, 1922. 21) Otsu, A.: A Histological Study of Sensory Nerve Endings in the Alimentary Canal of Human Being and Dog. Acta Sch. Med. Univ. Kyoto, 31 ; 103, 1953. 22) Rachmanow, A.W.: Zur Frage der Nervenendigungen in der Gefasse. Anat. Anz. Bd. 19: 555, 1901. 23) Seto, H.: a) Uber die Afferenten Nerven im Aortenbogen und im Herzen beim Menschen im Hinblick auf den Aorten und Herzreflexe. Arb. Anat. Inst. Sendai, 20; 1, 1937. b) Histological Observation of Muman Sensibility. Rinsho no Nihon 1; 1, 32, 1955. (in Japanese) 24) Stöhr, Ph. Jr.: a) Mikros'sopische Anatomie des Vegetativen Nervensystems. Springer Verlag. 62, 1928 . b) Zeitschrift fur Zellforschung und mikroskopische Anatomie. 16; 123197, 1932. c) Zur Nervenversorgung der Blutgefässe. Dtsch. Med. Wschr. 1933. d) Lehrbuch der Histologie und der Mikroskopischen Anatomie des Menschen. Springer Verlag. 1951. e) Zusammenfassende Ergebnisse über die Endigungsweise des vegetativen Nervensystems. Acta Neuro-Veg. X; 1-2, 1954. 25) Stöhr, Ph.: Lehrbuch der Histologie. Jena. 1930. 26) Sunder-Plassmann, P.: Untersuchungen über den Bulbus Carotidis bei Menschen und Tiere im Hinblick auf die Sinusreflex nach H. E. Hering, Ztsch. Anat. u. Entwg. 93; 567, 1930, 27) Takino, M.: Über die Innervation der Blutgefässe der Lunge beim Vogel. Acta Sch. Med. Univ. Kyoto, $\mathbf{X} \overline{\mathbf{v}}, 308,1933$. 28) Tello, D. F.: Dévelopent et Termininaison de Nerf dépreseur. Trav, Lab. Rech. Biol. de L'univ. Madrid. 22; 295, 1924. 29) Tschermak, A.: Über die afferente Innervation des Blutgefässystems Wien. med. Wschr. Jg. 74; 837, 1924. 30) Watanabe, M.: Über die sensible Innervation der Stammmgefässe in der Thoraxhöhle. Fol, Ender. Jap. Bd XIV; Heft 6, 43, 1938. 31) Weber, A.: Les bases morphologiques de la sensibilité artérielle. Acta Neuro-Veg. Bd VII; 1953. 32) Weddell, G.: The Anatomy of Pain Sensibility. Acta Neuro-Veg. Bd III; Heft 1-1, 1953. 33) Weddell, G. and Pallie, W.: The Value of "Spreading Factors" in the Demonstration of Tissue Neural Elements. Quartl. Jour. Microscop. Scien. 95, 1954. 34) Whitte- 
ridge, D.: Afferent Nerve Fibres from Heart and Lung in Cervical Vagus. Jour. Physiol.
107; 496, 1948. 35) Woolard, HH.: The Innervation of Blood Vessels. Heart, 13; 319, 1926.

\title{
和文抄 録
}

\section{大血管の求心性神経支配に関する組織学的研究}

\author{
京都大学医学部外科学教室第 2 講座（指導 青楖安誠教授）
}

大学院学生 鄭 逸㞎

Jabonero 氏神経鍍銀法を用い，成大の総頸動脈，

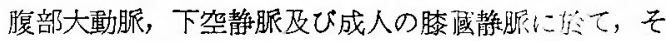
の壁内に求心性神経の形態及び分布を検索し，更に成

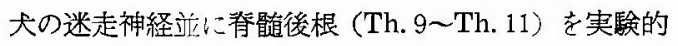
に切断し, 各動, 静脈壁内末梢神経軸索の二次的変性 を追求し，之等の結果より血管壁の求心性神経支配に 関し以下の如き結論を得た。

1) 成大の総钼動服及び腹部大動脈の中膜層に於 て，太き波状走行を呈する神経繊維を認め，之等の神 経繊維は輪状，及び放線状に分布し，更に縦に連絡し ているのが認められた。

2）成犬の下空静脈に於ては，外膜より進入した神 経繊維の内膜直下迄達するのが認められた。

3）成人の滕掝静脈に於ては，比較的厚き中膜の平 滑筋束に沿つて波状走行を呈する太き神経纎維が認め られたが，内営には認められなかつた。

4）静脈に於ける神経分布は動脈に比へて遥かに少
W.

5）之等神経緎維は，殆んど遊離終末を以つて結締 織間に終り，筋細胞との接触或は，細胞内進入は言め られなかつた。

6）外膜に於て Jabonero の云う “Syncytium nerveux: を多数認めたが，中膜及び内膜に於ては 網様構造を呈する自律神経性終末を認め得なかつた， 然し時に繊細な，神経繊維を中膜に認め，之は或は自 律神経性の緘維ではないかと思はれる.

7)迷走神経及び青䯣後根切断実験に於て，中膜に 軸索变性像を認めた. 従つて血管壁の求心性神経は, 迷走性，脊髄性の二重支配を受けている事が判明し た。

8）ヒアルロニダーゼの応用に依り, 困難視され た. 血管神経染色を鮮明に且つ短期間 (一週間) の固 定で鍍銀染色する事が出来た。 
Figures

Y. II. Cheng.

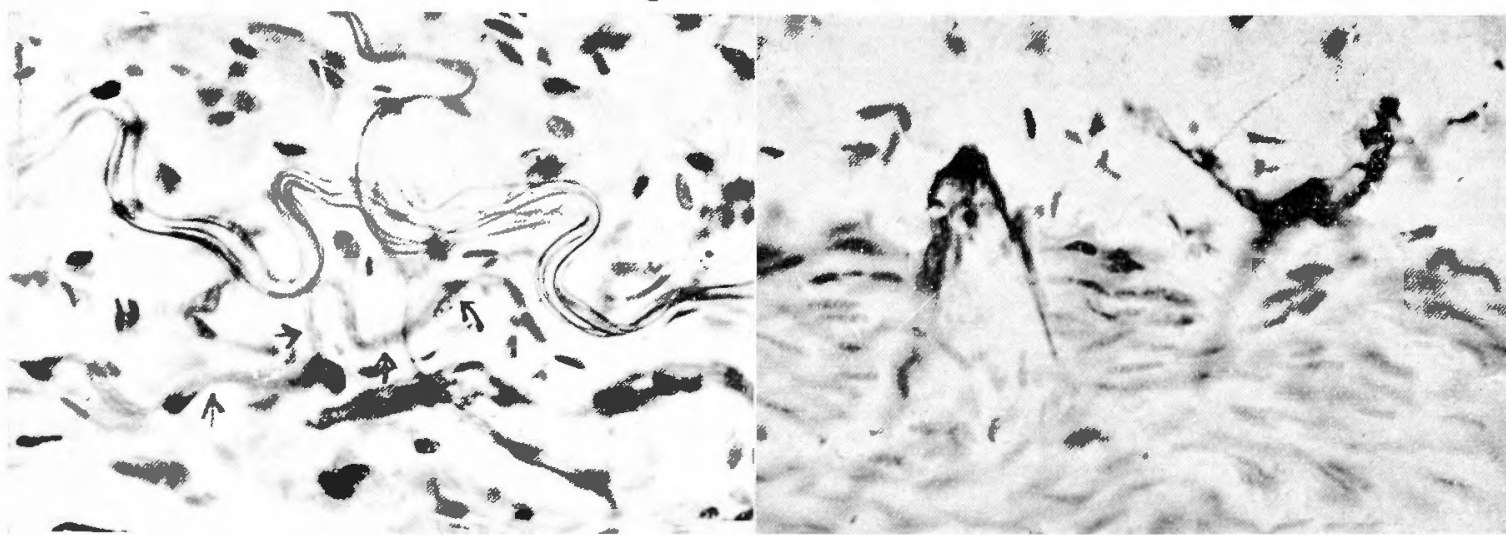

Fig. 1. Syncytium nerreux in the adrentitia.

Common carotid artery. Dog. Cross section.

Fig. 4. Nerve fibres penetrate into media from $\times 400$.

adventitia. Common carotid artery. Dog.

$\times 400$.

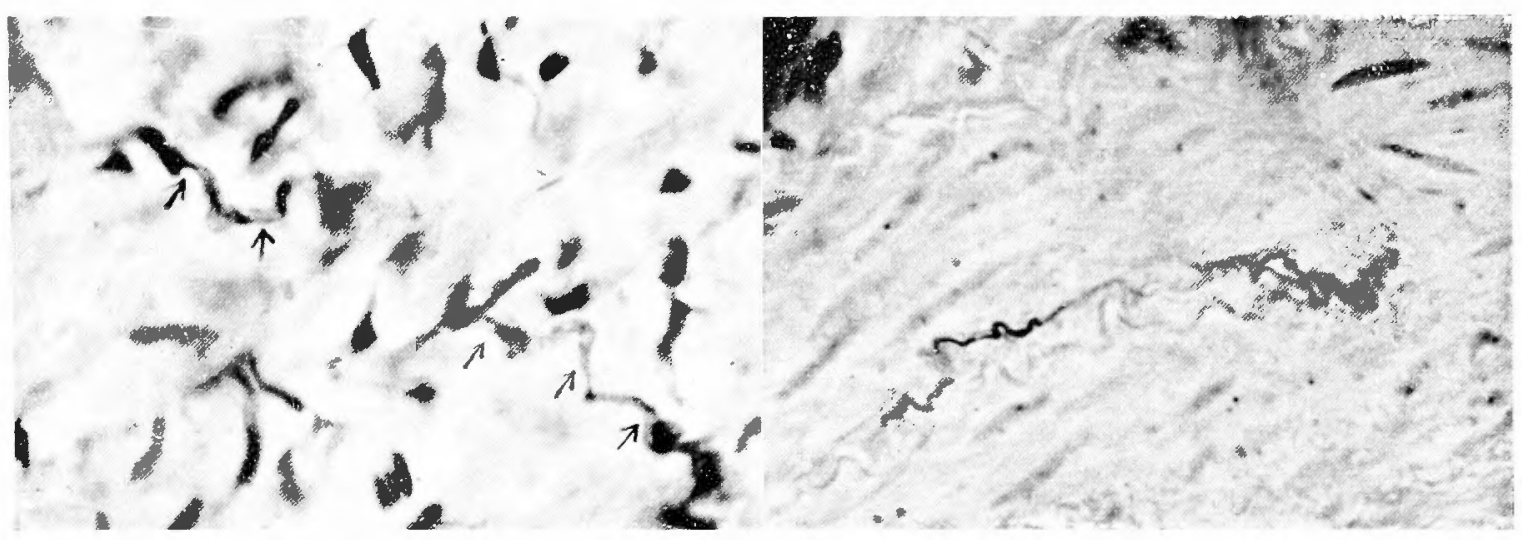

Fig. 2. Syncytium nerveux in the adventitia. Abdominal aorta. Doz:
Fig. 5. Circular running nerve fibre along elastic fibres. Common carotid artery. Dog.

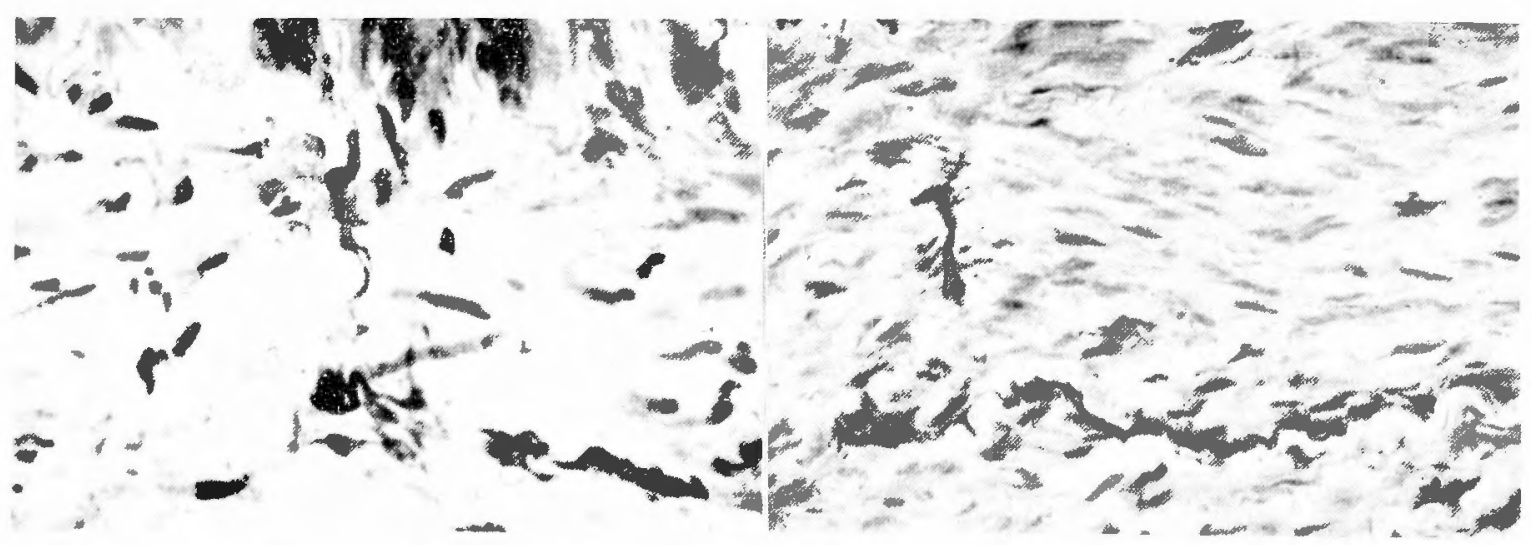

Fig. 3. Nerve fibre venetrates into media from adrentitia. Comm un carotid artery. Dog.
Fig. 6. Radial and circular running nerve fibres in the media. Common carotid artery. Dog. 


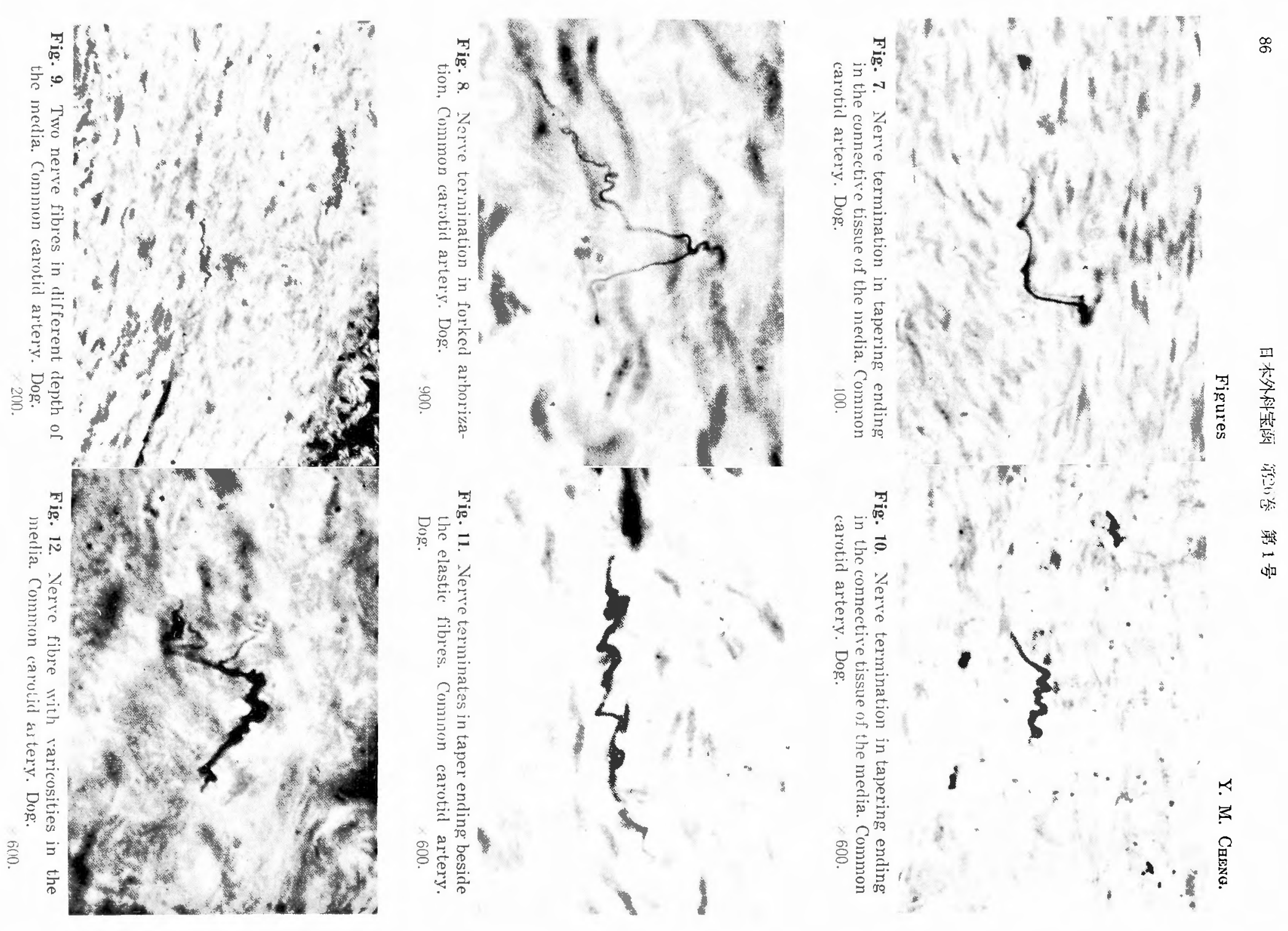




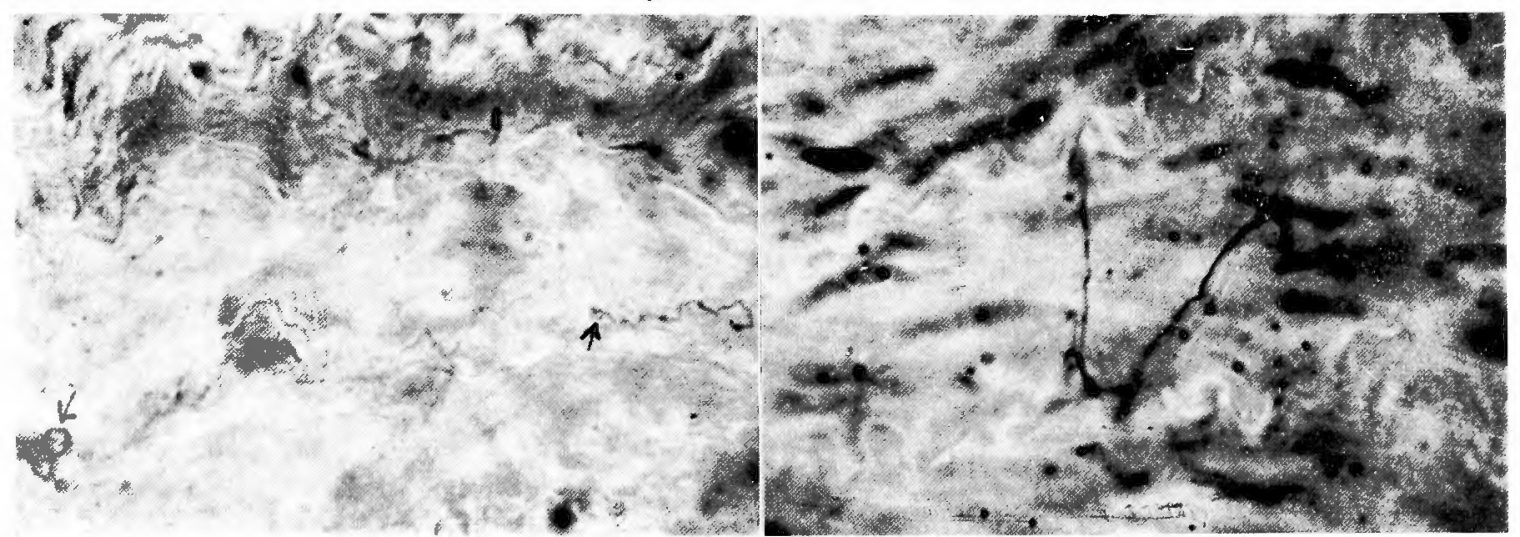

Fig. 13. Nerves with varicosities and loop-like ending in the media. Common carotis art. Dog.
Fig. 16. Nerve fibre between two layers of elastic fibres. Common carotid artery. Dog.

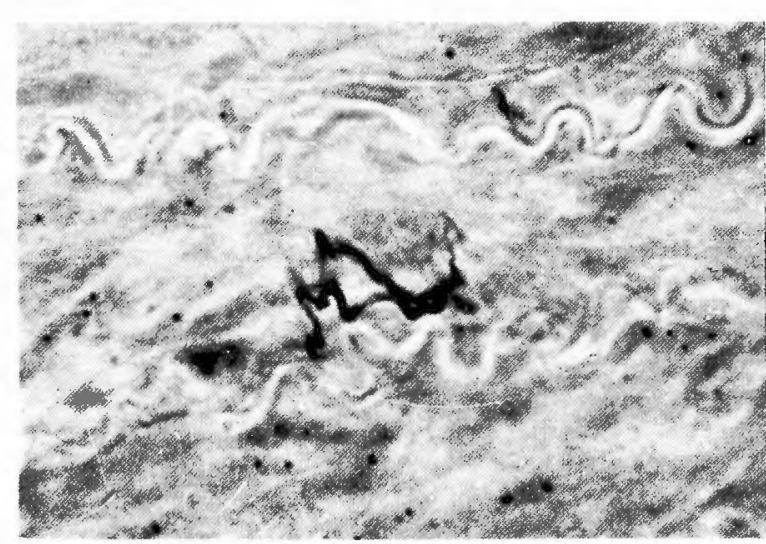

Fig. 14. Nerve terminates in loop-like ending: Common carotill artery. Dog.

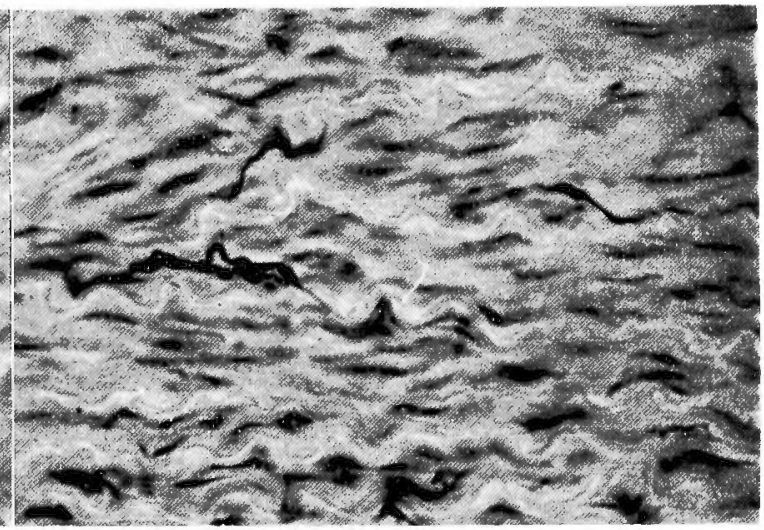

Fig. 17. Nerves cross over to other layer of elastic fibres. Common carotid artery Dog.

100.

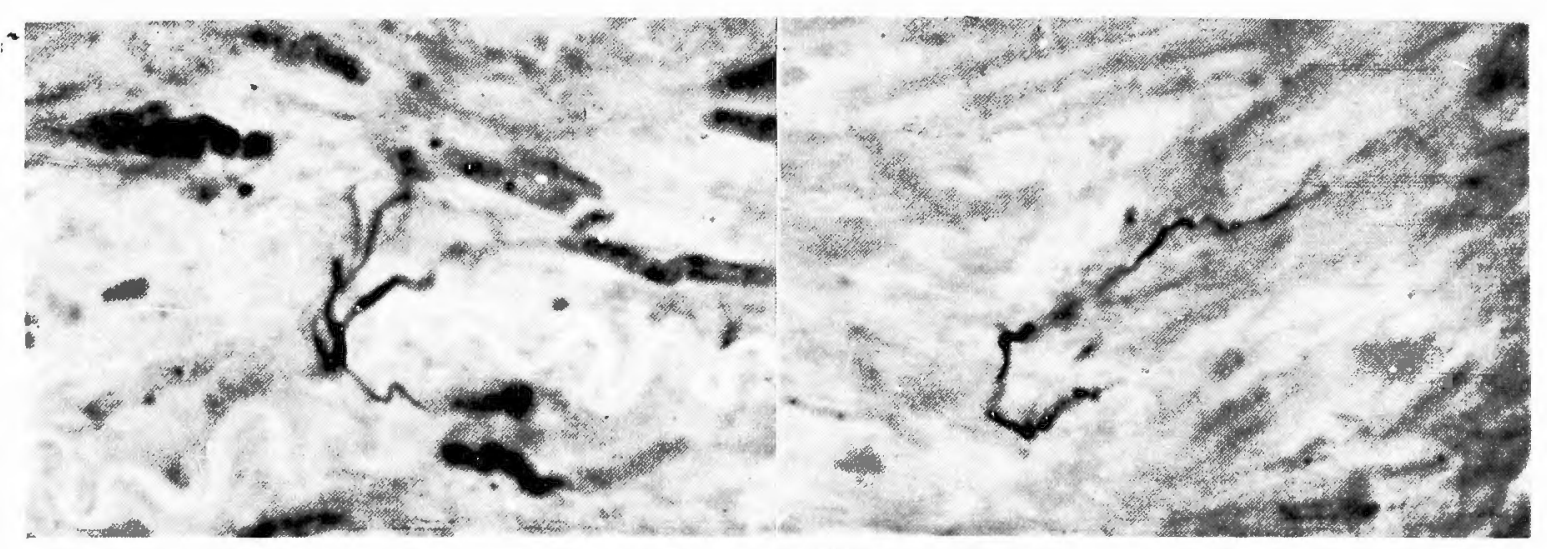

Fig. 15. Nerve ending shows complicate arborization. Common carotid artery. Dog.
Fig. 18. Verticle running fibre with horizontal branch. Longitudiral section. Common carotid artery. Dog. $\times 600$. 
Figures

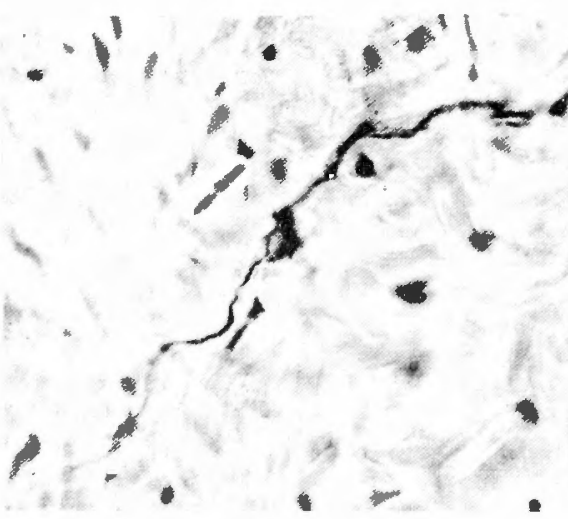

Fig. 19. Nerve fibre running from adventitia into media in oblique direction. Longitudinal section. Abdom. aorta. Dog.

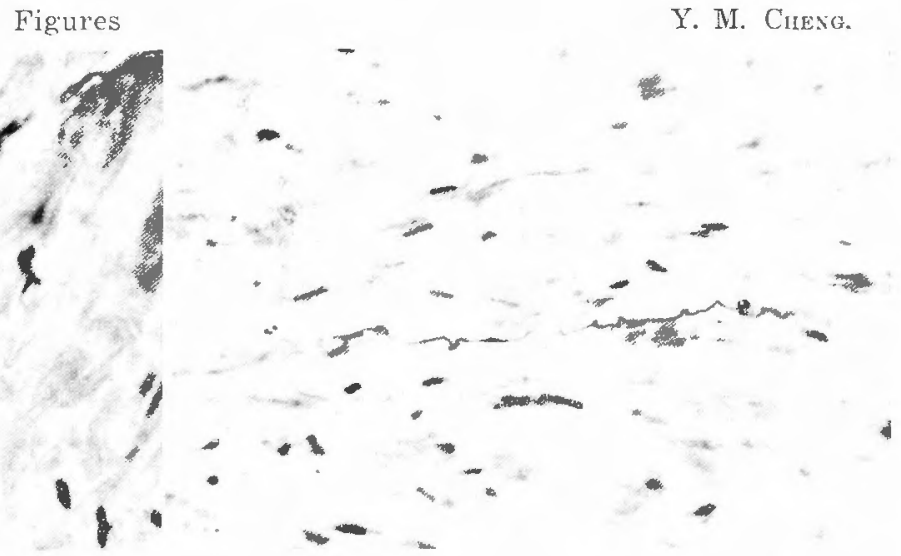

Fig. 22. Nerve fibre along clastic fitores in the media. Abrlom. aorta. Dug:

100.

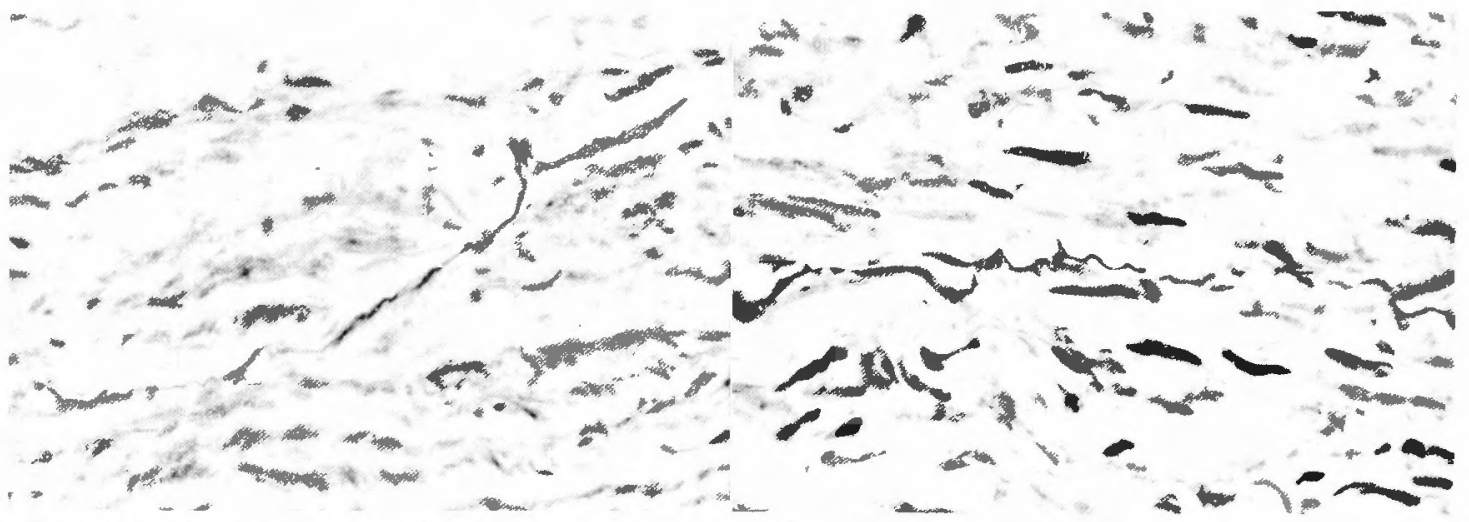

Fig. 20. Ramification in the outer layer of Fig. 23. Wary nerve along the elastic fibres media. Abdom. aorta. Dog:

400 .

in the merlia. Abtom. aorta. Dog. $\quad 600$.

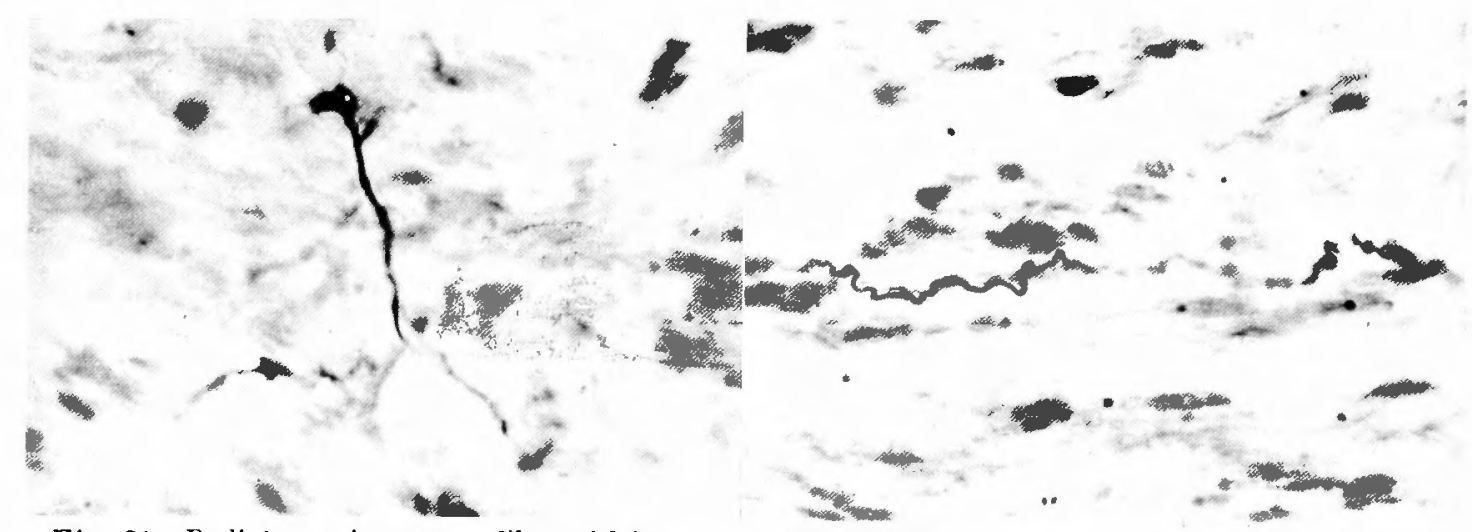

Fig. 21. Radial running nerve fibre with branches in circular direction along elastic filures. Abdon. aorta. Dog. $\times 900$.
Fig. 21. Wary nerve terminal with taner ending in connective lissuc for the imedia. Abdom. aorta. Dog. 
Figures

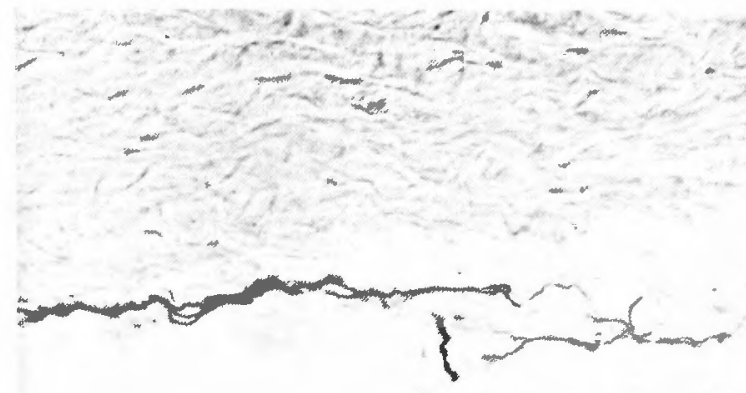

Y. М. Cheng.

Fig. 25. Nerve ramification in media. Abdom. aorta. Dog. $\times 400$.

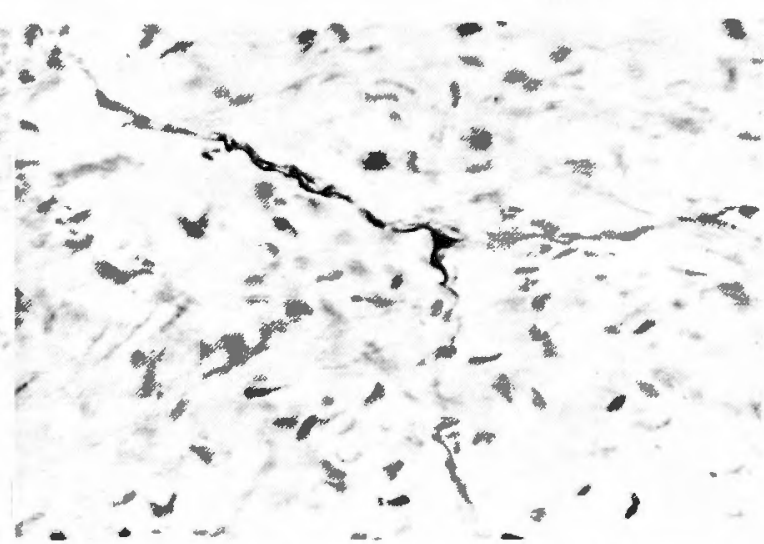

Fig. 28. Branches in verticle and horizontal directions. Longitudinal section. Abdom. aorta. Dog. $\times 400$.

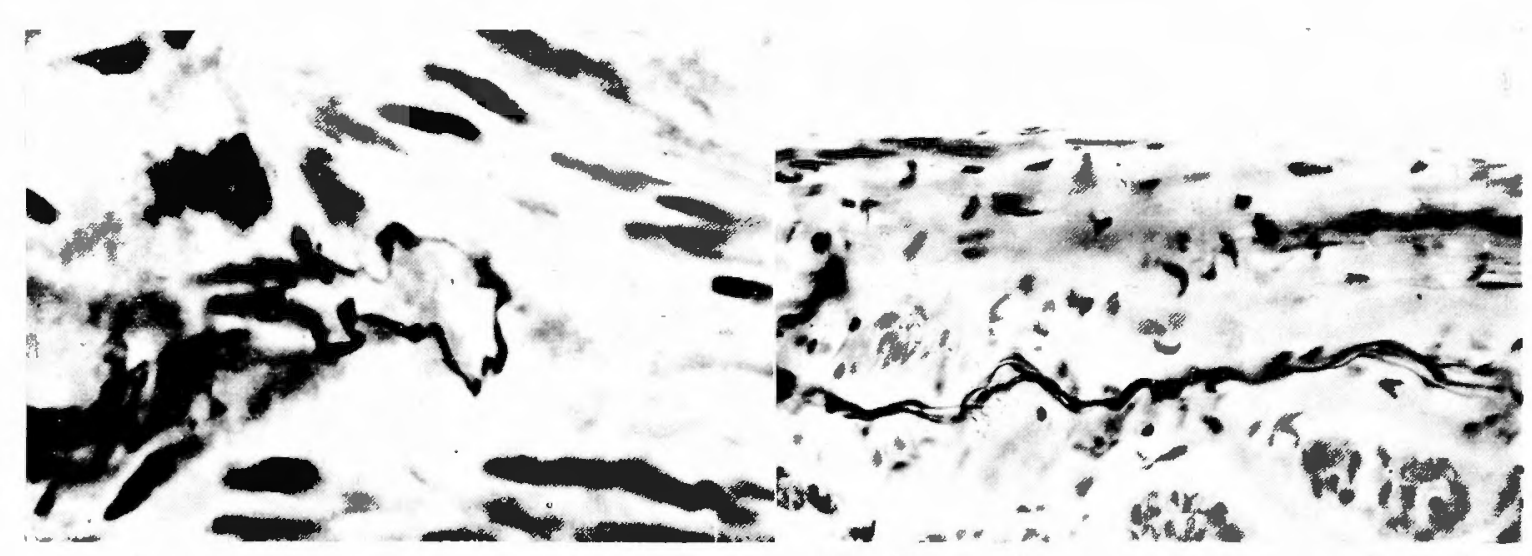

Fig. 26. Nerve terminal forming a large loop in the media. Abdom. aorta. Dog. $\times 900$.

Fig. 29. Bundle of nerve fibres in adventitia. Vena cava. Dog. $\times 400$.

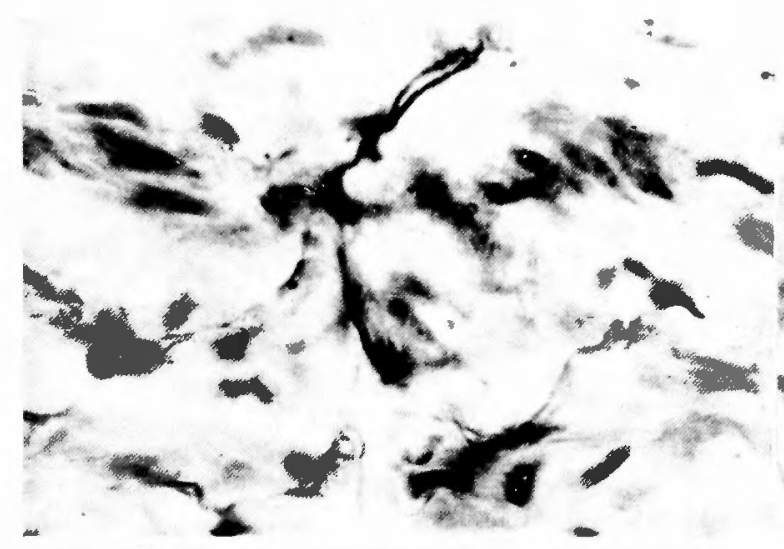

Fig. 27. Nerve termiral with complicate arborization in the media. Abdom. aorta. Dog. $\times 900$.

Fig. 30. Nerve fibre entering media from adventitia. Vena cava. Dog. $\quad \times 900$. 


\section{Figures}

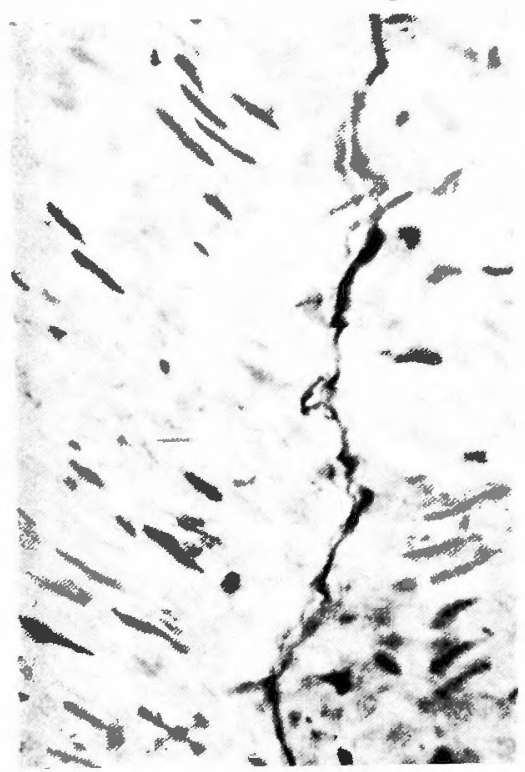

Fig. 31. Nerve fibre with reticulated swellings and varicosities running in longitudinal direction in the media. Abdom. aorta. Dog.

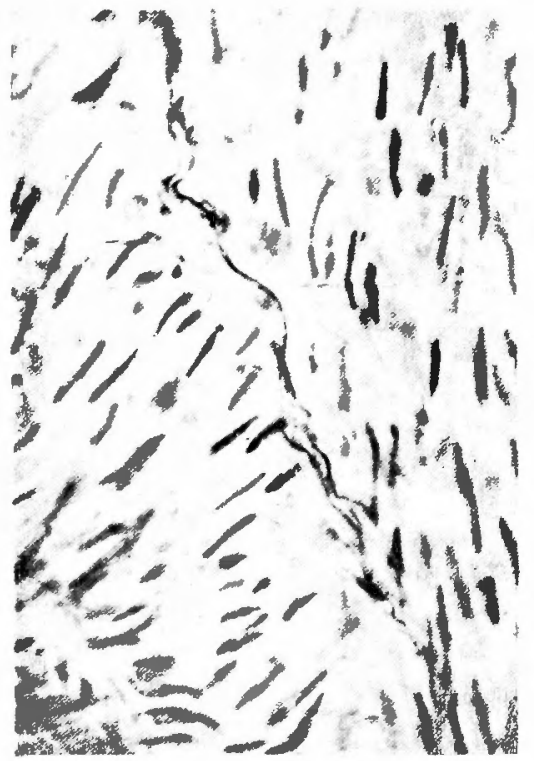

Fig. 32. Nerve fibre with reticulated swellings running in long itudinal direction in the media. Longitudinal section. Abrlom. aorta. Dog.
I. M. Cheng.

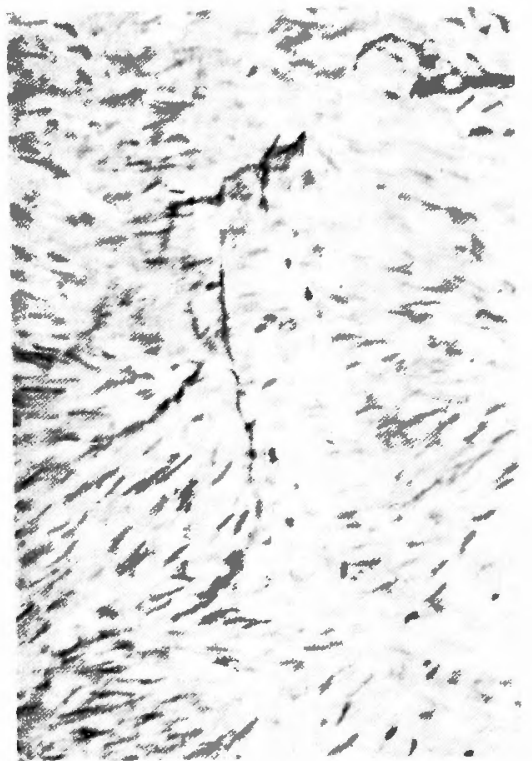

Fig. 33. Longitudinal nerve fibre with horizontal branches in the media. Longitudinal section. Abdom. aorta. Dog. $\times 100$.

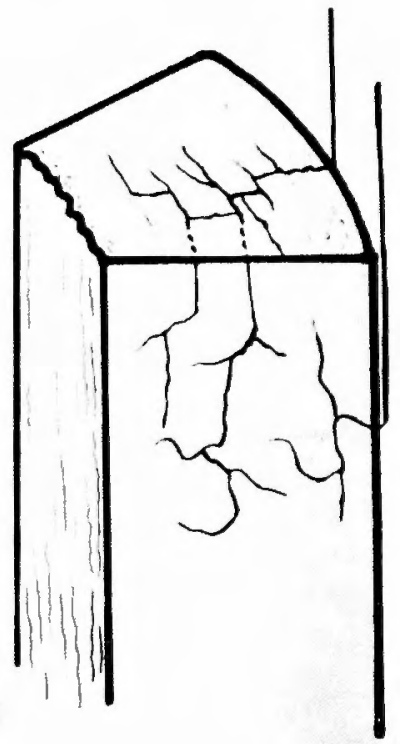

Fig. 34. Schema showing the pattern of afferent innervation of arterial wall. 
Figures

Y. M. Chenti.

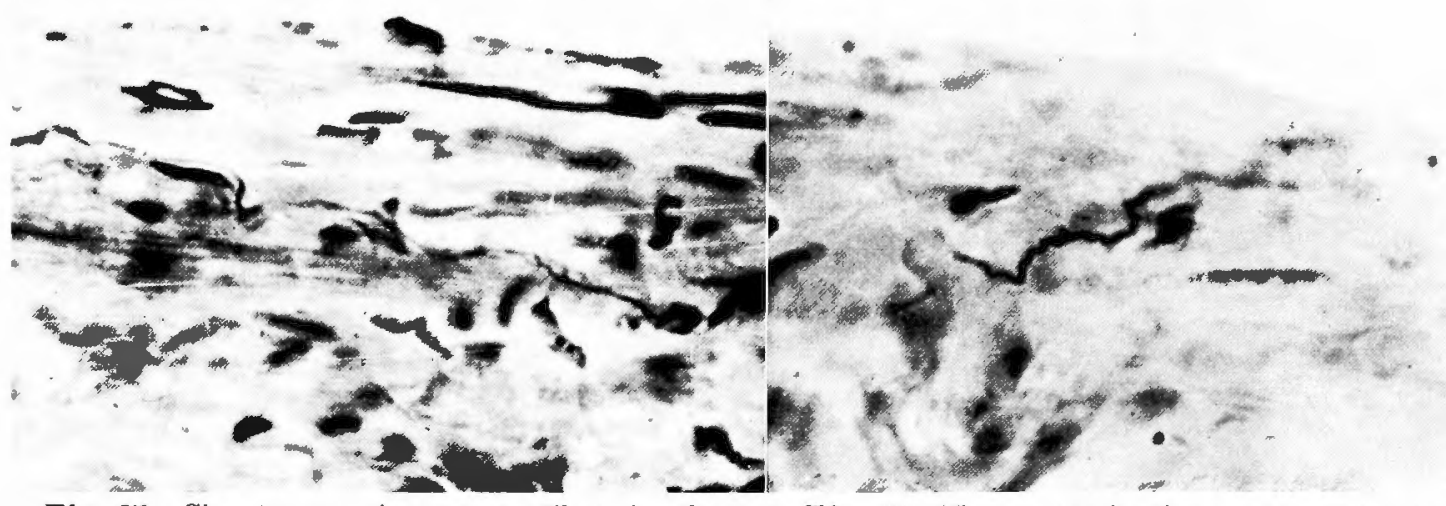

Fig. 35. Circular running nerve fibre in the media. Vena cava. Dog.

Fig. 38. Nerve termination in the intima. Vena cava. Dog:

$\times 900$.

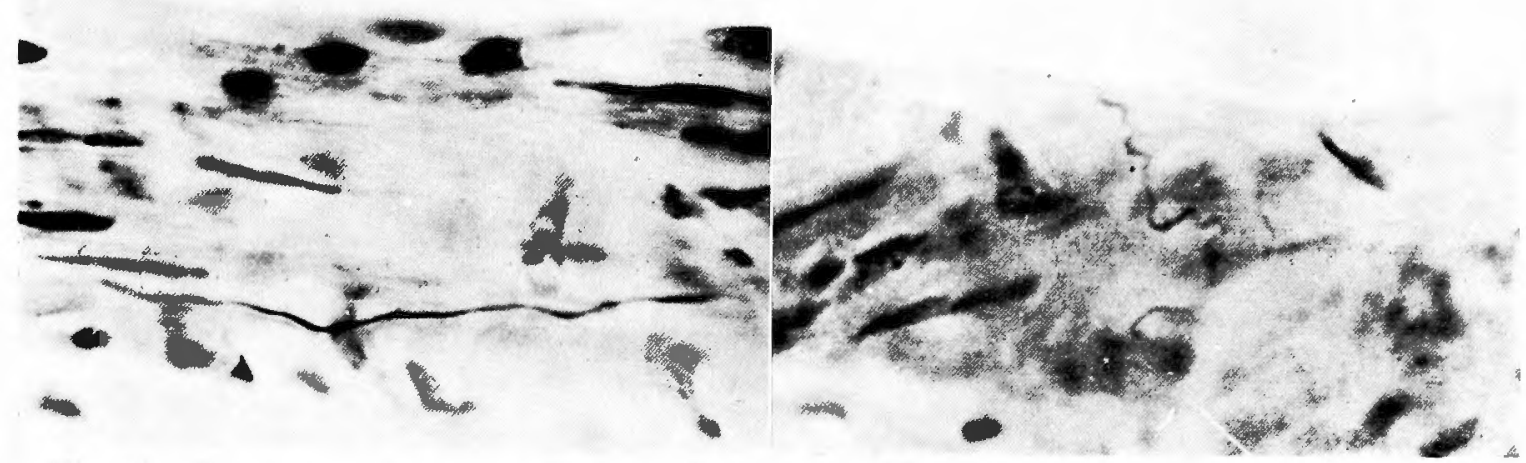

Fig. 36. Circular running nerve fibre in the media. Vena cava. Dog.

Fig. 39. Wavy nerve termination in the intıma. Vena cava. Dog. $\times 900$.

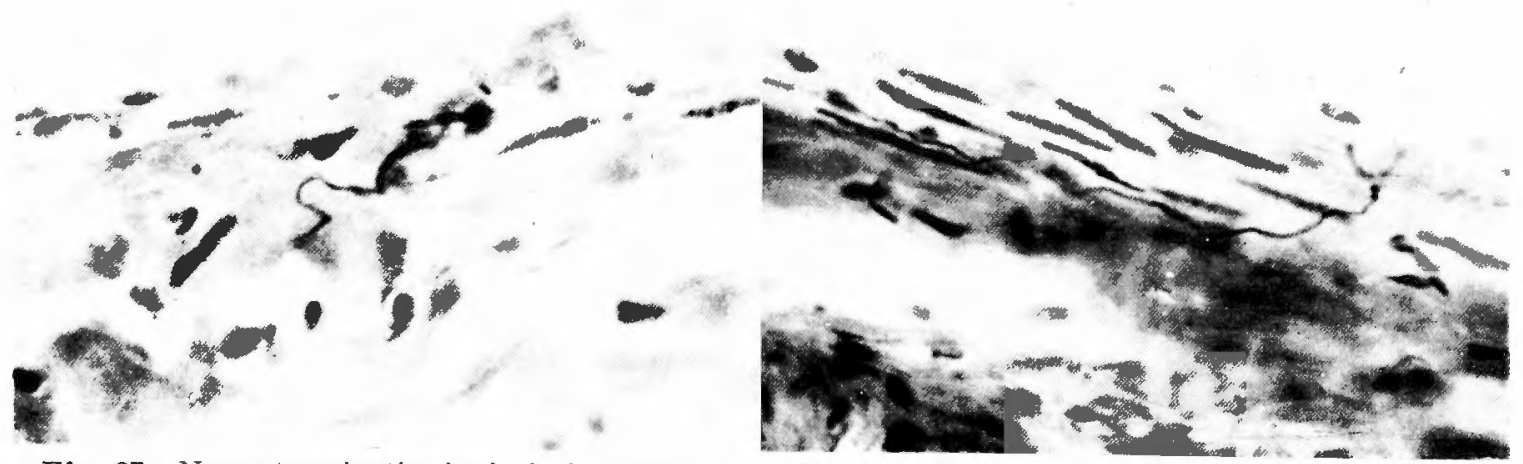

Fig. 37. Nerve termination in the intima, where round nuclei of endothelial cells are observable. Vena cava. Dog. $\times 900$.

Fig. 40. Nerve termination with forked ending in the intima. Vena cava. Dog. $\times 900$. 
Figures

Y. M. Cheng.

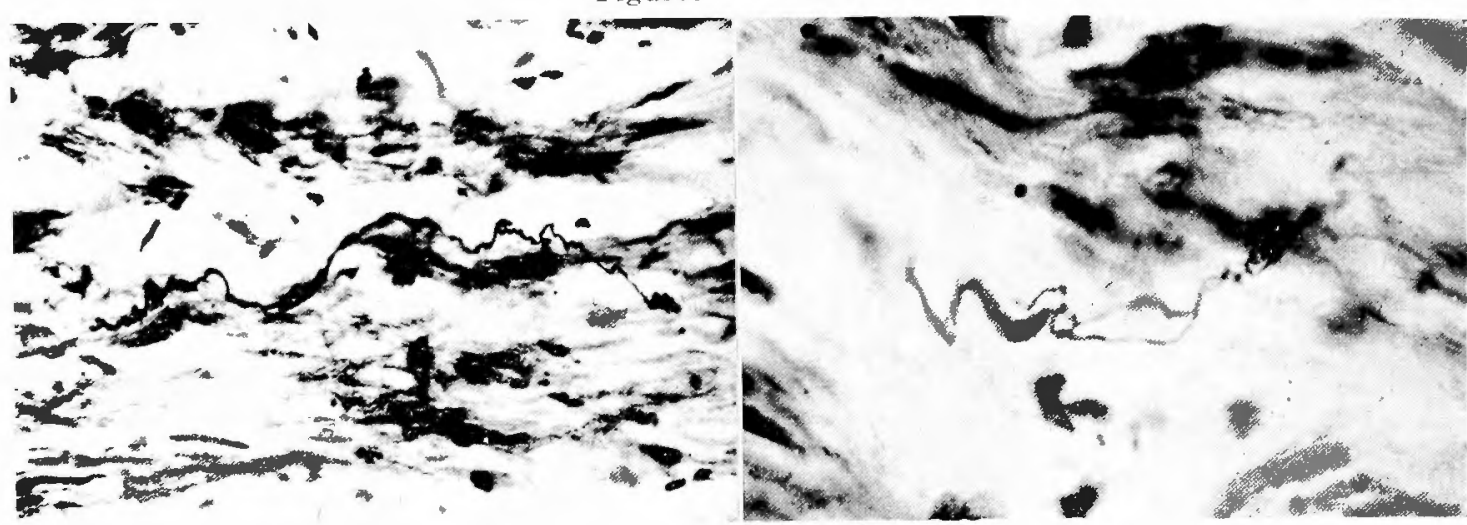

Fig. 41. Thick wayy nere fibre running in circular direction in the media. Popliteal vein. Human. ('russ section. $\times 400$.

Fig. 43. Nerve termination in the connective tissue between smooth muscle bundles of the media. Popliteal rein. Human. $\times 900$.

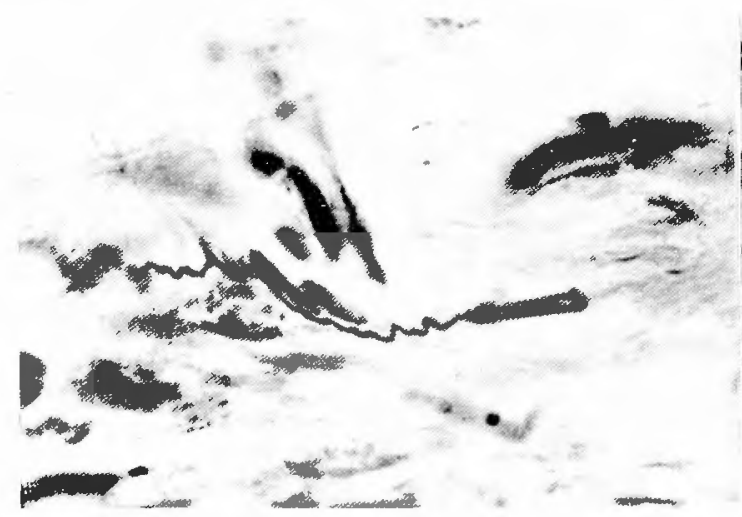

Fig. 42. Thick nerve fibre in the media. Popl1teal vein. Human. $\times 900$.

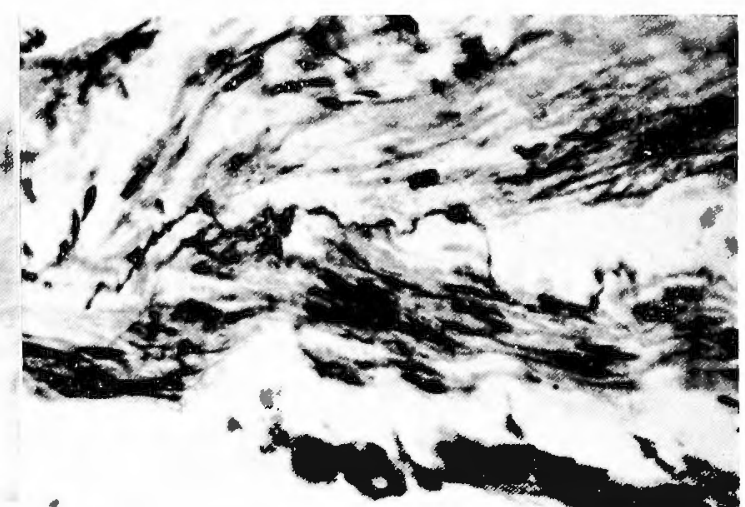

F.g. 44. Thick wavy nerve fibre with varicosities in the media. Human popliteal vein.
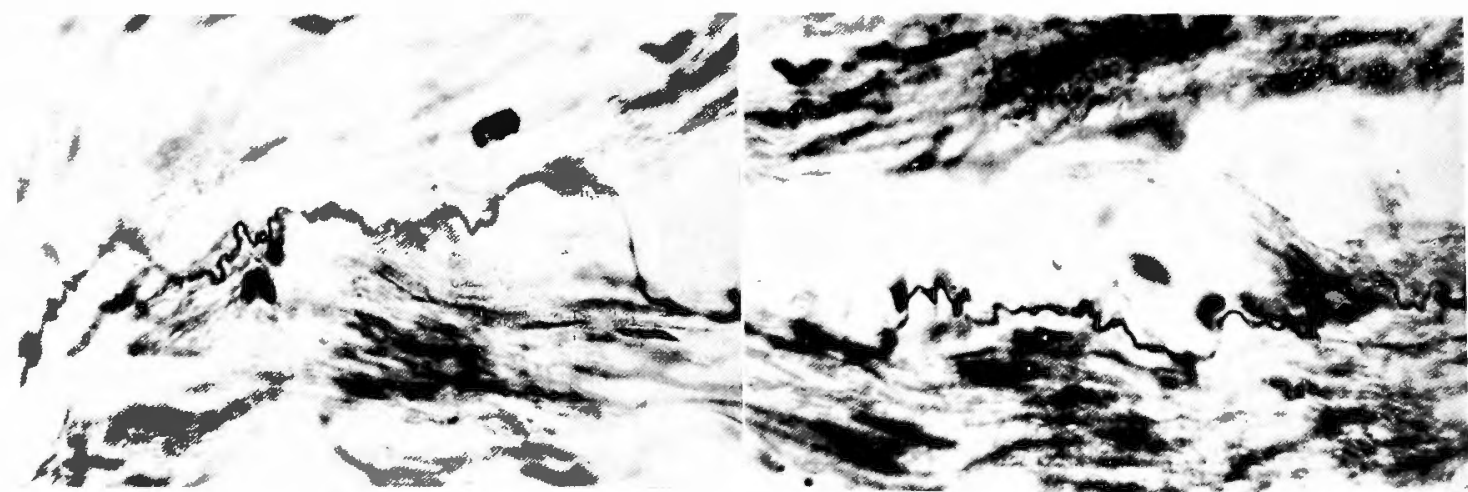

Fig. 45 (a). Long thick wayy nerve fibre with varicositics running in circular direciton in the media. Human popliteal vein. $\times 900$.
Fig. 45 (b). Continuation of the nerve fibre in Fig. 15 ia 
Figures

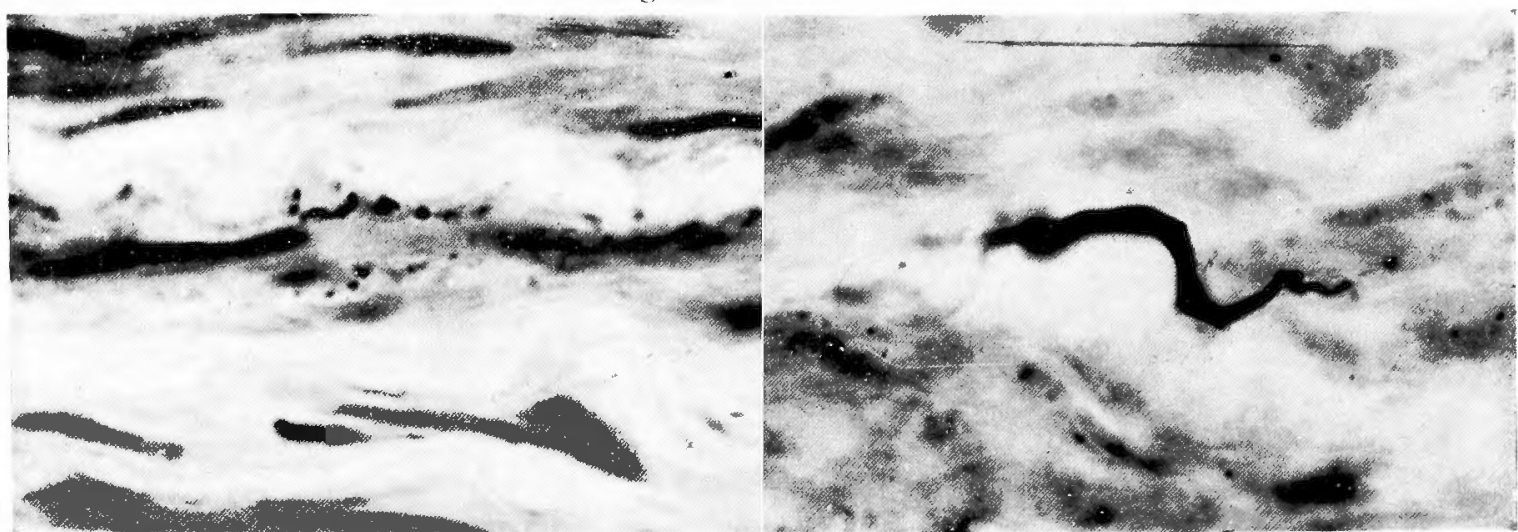

Fig. 46. Degenerated axis-cylinder along the elastic fibres 6? days after vagotomy. Abdom. aorta. Dog.
Fig. 49. Degenerated nerve fibre showing strong swelling 5 days after vagotomy. Common carotid artery. Dog.

$\times 900$.

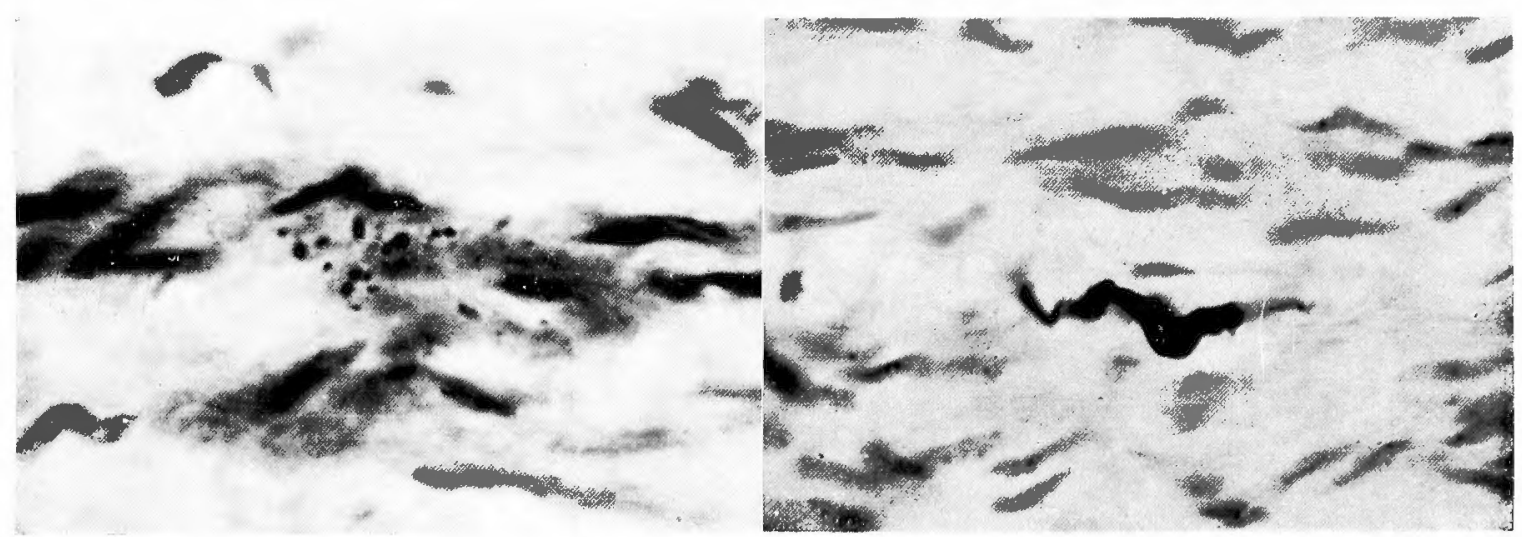

Fig. 47. Granular degeneration of axis-cylinder scattered in connective tissue of the media. 62 days after vagotomy. Abrom. aorta. Dog:
Fig. 50. Degenerated nerve fibre showing strong swelling 5 days after vagotomy. Common carotid artery. Dog: $\times 900$. $\times 900$.

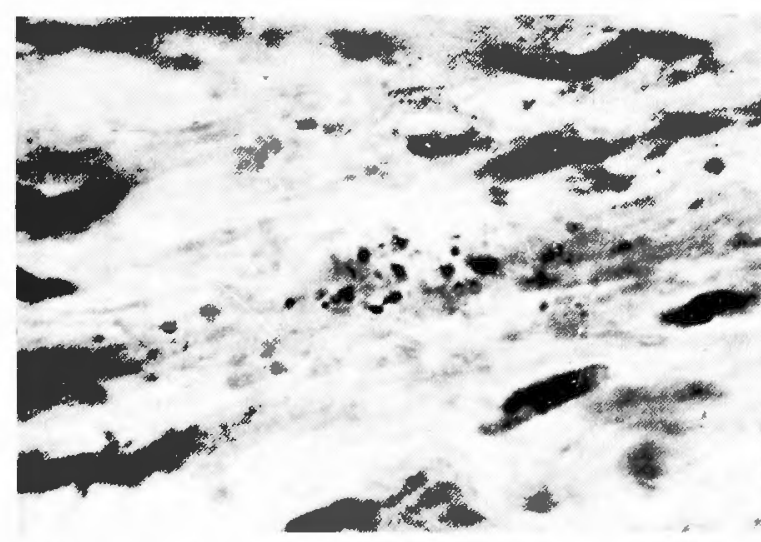

Fig. 48. Granular degeneration of axis-cylinder in the media, 7 days after bilateral vagotomy. Abdom. aorta. Dog. $\times 900$

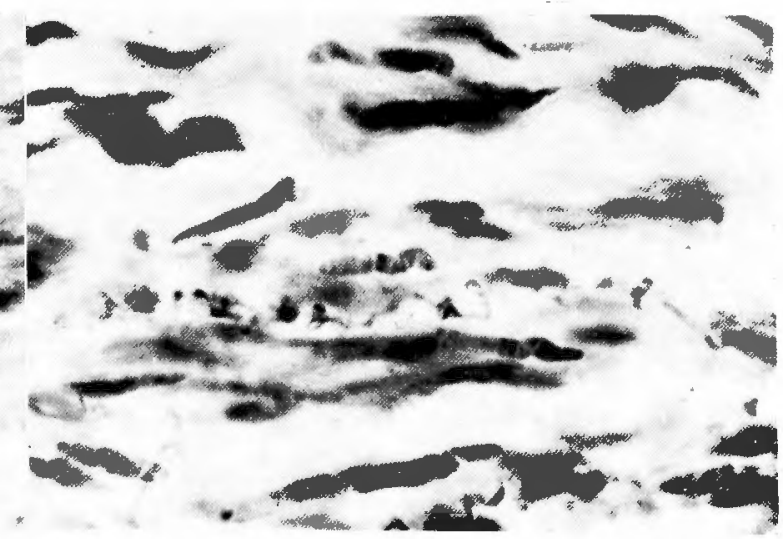

Fig. 51. Degenerated nerve fibre with vacuoles and partial severance, 5 days after vagotomy. Common carotid artery. Dog: $\times 900$. 
Figures

Y. M. Chens.

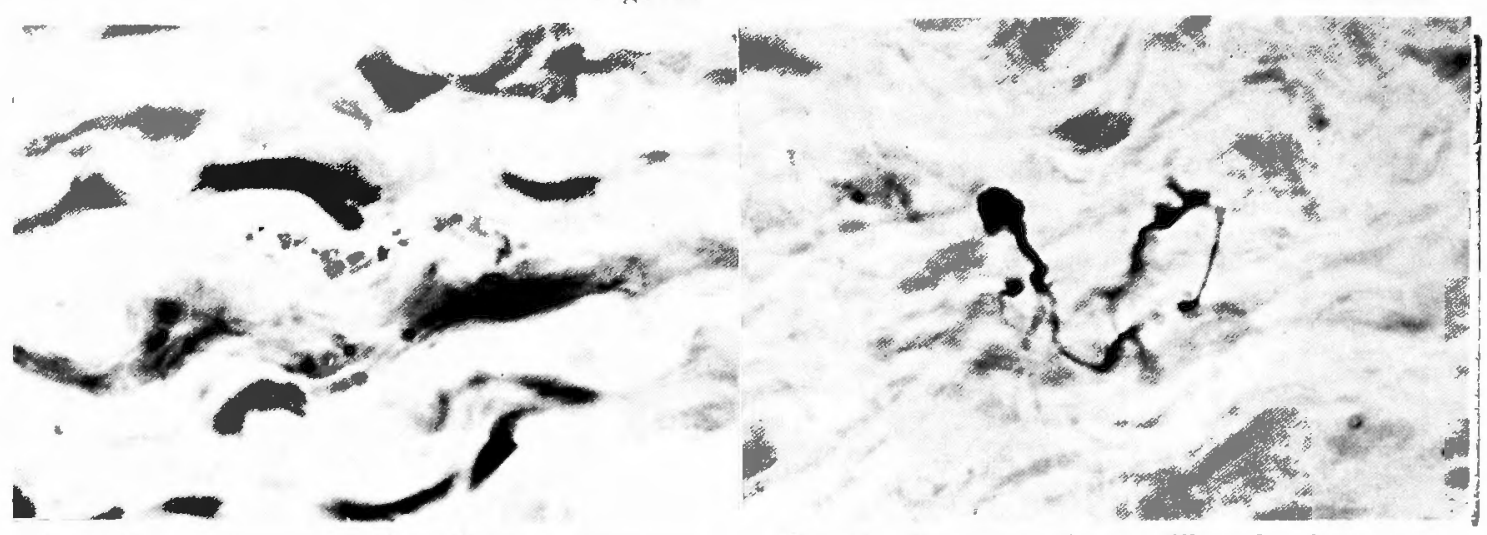

H15. 52. Negenerated axis-cylunder in the media, 3 days after post. rhizotomy. Th. 9, 10, 11 Abdom. aorta. Dog.

900 .

Fig. 54. Degenerated nerve fibre showing strong rugged swelling, 3 days after post. rhizotomy.

Abrom. aorta. Dog. 900.

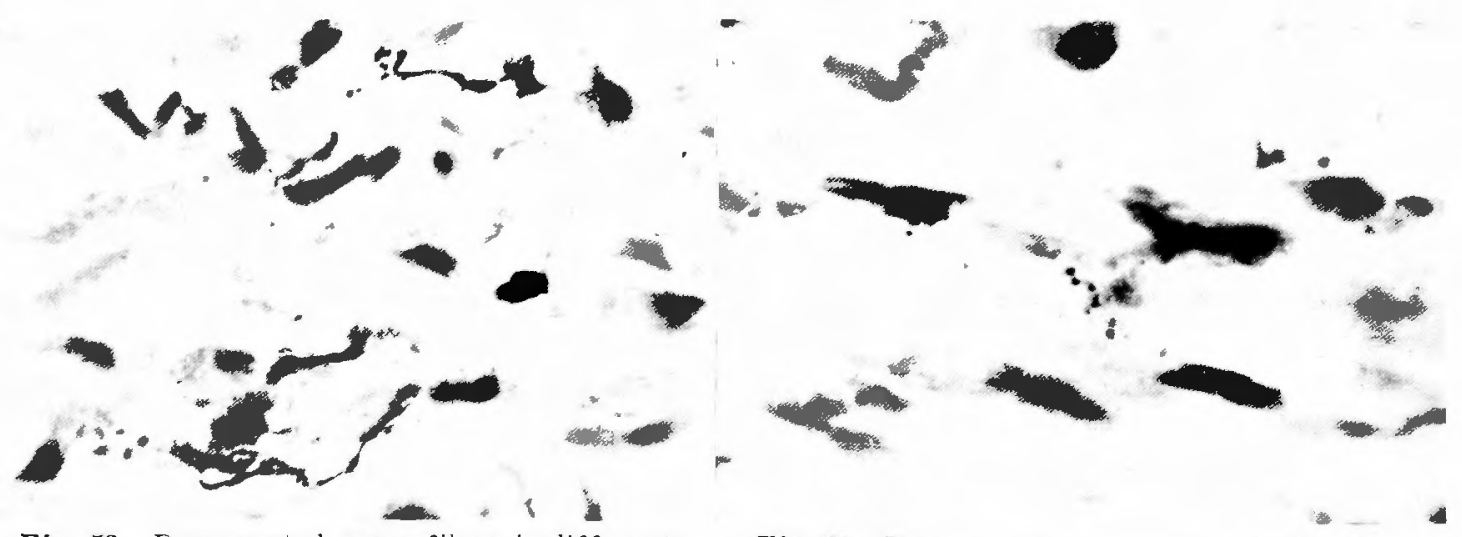

Fig. 53. Degenerated nerve fibres in different depth of the media, 3 days after post. rhizotomy. (Th. 9, 10, 11.) Abdom. aortat. Dog. $\times 900$.

Fig. 55. Degenerated axis-cylinder partly absorbed, 5 days after post. rhizotomy. Th. 9,10 , 11). Aluturn. aorta. Dog. $\times 900$. 


\section{—SKYLUXMINOR}

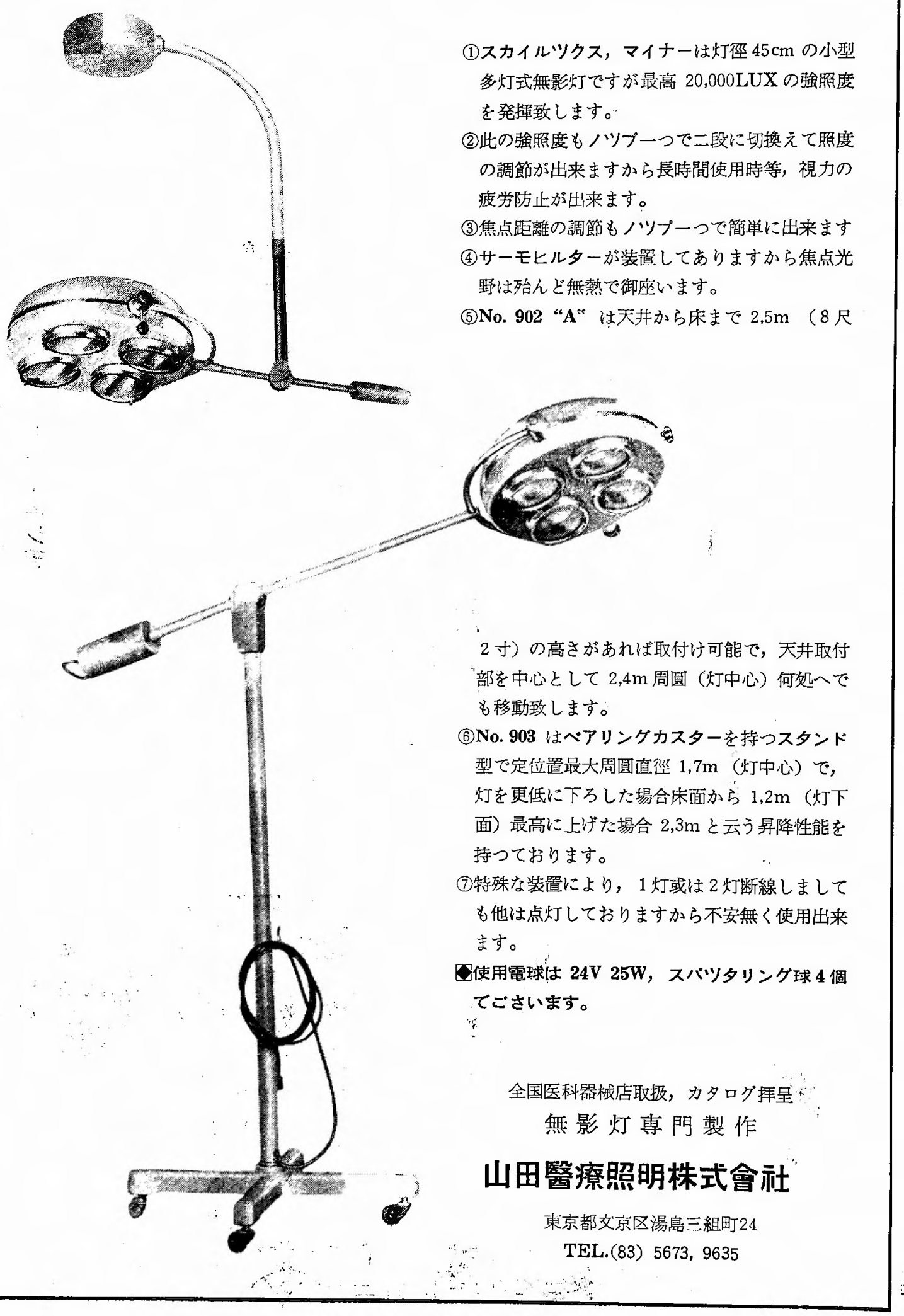



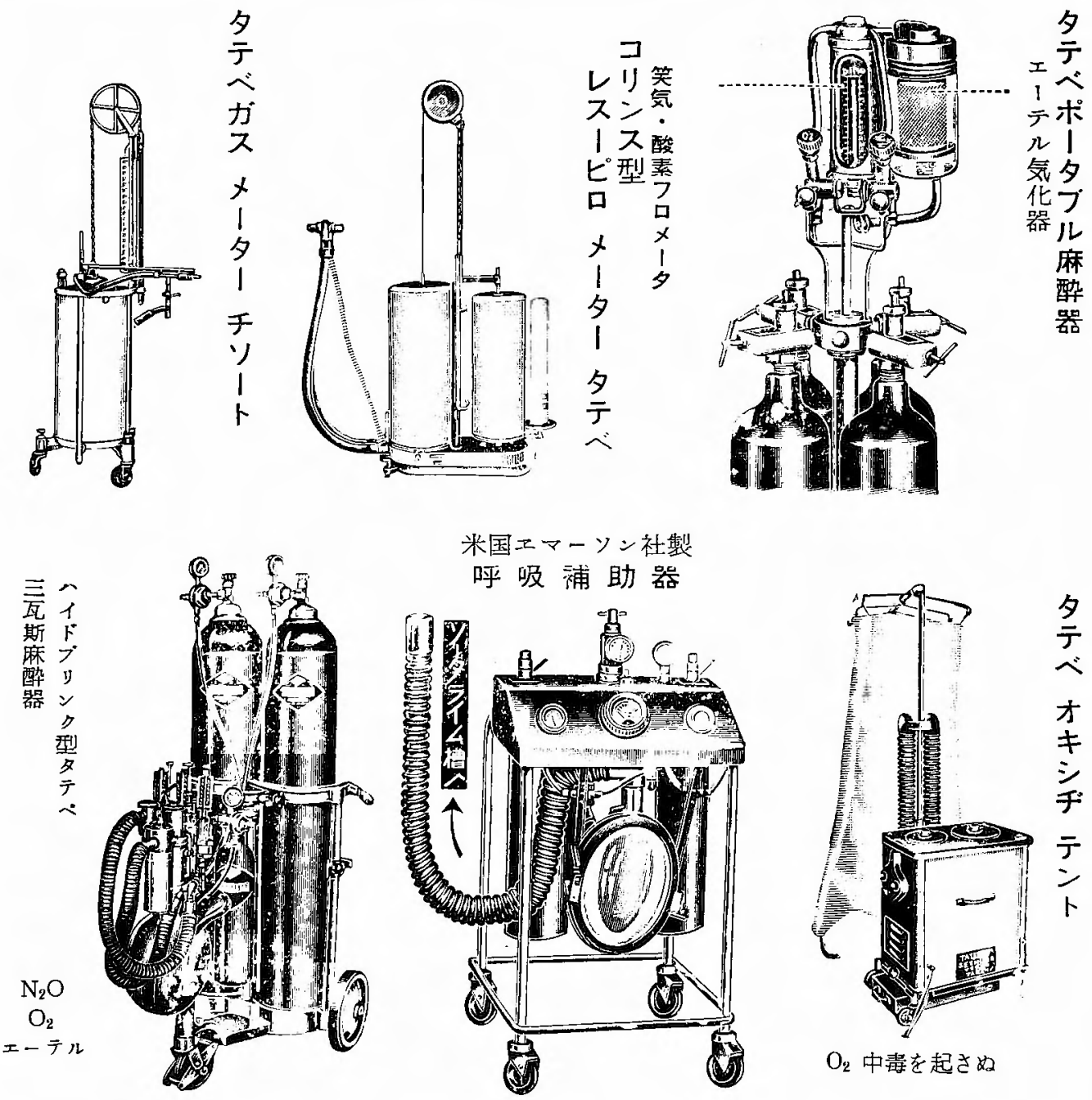

$\mathrm{O}_{2}$ 中毒を起さぬ
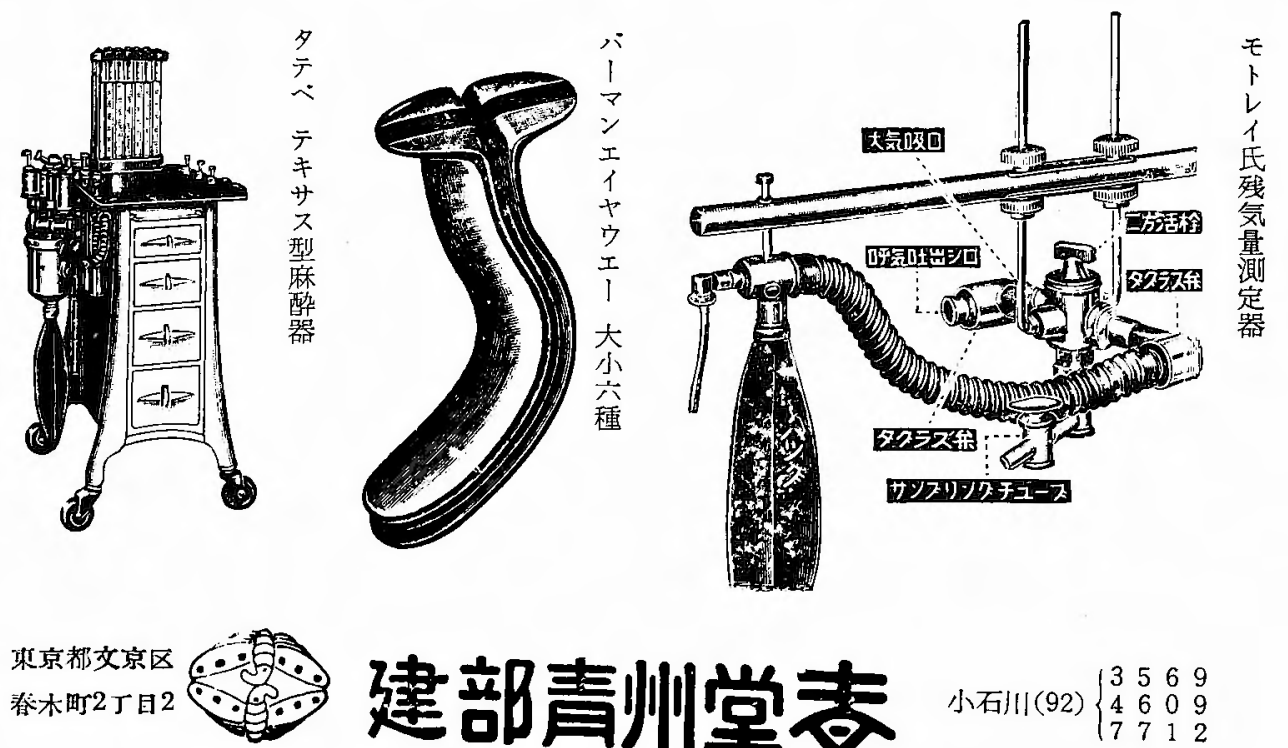